\title{
The Mixture Japanese and Western Style in the Image of the Governor-General's Residence of Taiwan Under Japanese Rule ${ }^{1}$
}

\author{
Lee Chao-Ying \\ National Dong Hwa University, Hualien, R.O.C., Taiwan
}

\begin{abstract}
This paper focused on Japan who was as a new colonial government in Taiwan under Japanese rule, during the period of which took official buildings or urban planning mainly of a series of Western European-style architecture as a ruler's cultural identity and a modern Taiwan policy. However, in the context of East Asian modernity, the basic colonial not only mixed Eurocentric, but also included Japan Center and the interaction between the two. Therefore, the scope of research and discussion shall have regarded to the non-Western, non-white nature of the Japanese Empire, and its colonial/modernity construction is another new model. Taiwan Governor-General's Residence as the Governor-General's residence for Japanese government combined administrative office, daily living, and social life, showing a symbol of Japan's colonial ruling class, and a hostel to greet Japanese royal family and the nobility from time to time. As a mansion of both Western Baroque and Japanese style, its architectural design has class meaning, therefore it featured with a class-separation building, also combined the leisure of Western high society. The associated festivals at that time included tea party, fairs and royal family welcoming pilgrimage, the part of which with a strong political implication. This paper mainly uses the images of the Taiwan Governor-General's Residence during the Japanese rule period and the literature at that time to restore the mixed taste and Japanese-Western style of Taiwan at that time. The Japanese colonists ruled the complex interactions of different ethnic groups in Taiwan.
\end{abstract}

Keywords: colonial, Taiwan Governor-General's Residence, Japanese-Western style, image

\section{Introduction}

For two decades, a variety of important opinions have questioned the role of the West played in history, modernity, and fatalism. The scholars of Southern America have developed and theorized the colonial concept - established the Eurocentric view in history, civilization, and culture. They did not consider modernity originated in Western Europe and gradually expanded throughout the globe, but produced due to colonial violence (originated in discovery of America). In short, the coloniality is the bottom and possible conditions of modernity. Euro centrism is just actively trying to secure the myth, the modernity as a unique Western product. Therefore, anti-Euro centrism becomes a major political-cultural issue of coloniality. However, in the context

\footnotetext{
1 This paper has been presented in 2016 Summer University, The Colonial Unconscious August 22-23, Trentels, France De-colonizing Philosophy August 24-27, Toulouse, France, hosted by Toulouse-Le Mirail University, National Chiao Tung University; also presented in 2019 Annual Conference of Taiwan Art History Association, March 30-31, Taiwan Soka Association, the Zhishan Art Centre, hosted by Taiwan Art History Association.

Lee Chao-Ying, Associate Professor, Department of Ethnic Relations \& Cultures, National Dong Hwa University, Hualien, R.O.C., Taiwan.
} 
of East-Asian modernity, coloniality is not only the foundation, and mingles with Euro centrism, but also encompasses Japan-centrism. In the interaction between Euro-centrism and Japan-centrism, as well as in the context of East Asia, we must take into account non-Western and non-white nature of the Japanese Empire, and how the concept of its coloniality/modernity forms, and cultural and political issues on anti-Euro-centrism and anti-Japan-centrism constituted from the spatial journey personally experienced by the colonial peoples (Ching, 2006, pp. 53-71).

Viewed from the perspective of colonial history in the Japanese rule, due to the change of regime, involving new European style, it flaunted two special modernity meaning: The first is the new Japanese government marked a new taste through Western European style to segment the Chinese style of previous Qing Dynasty. The second is the concept of co-existence referred in the modernity; namely, Japanese architecture and European architecture coexisted in a same building are not incompatible. Here "and" marks no conflict between, but co-existence of tradition and modernity, so that European styles and Japanese new styles co-exist.

\section{The Modernization of Colonial Characteristics/With Europe Modernization as a Model}

\section{The Modernity of European Colonial Characteristics}

According to Denna Jones's argument, in 17th and 18th centuries, the first wave of Europe spread to imperialism in Asia, Africa, and the Americas mainly in Spain and Portugal, and the second wave was France, Britain, Italy, Portugal, Germany, Belgium. European powers began to consolidate their power in the New World, through occupying the land of the New World and colonizing. Convinced that European civilization is higher than other regions and cultures, the colonists showed a style of victors and became a model of non-European. They believed that they have a mission and a vocation to the world civilization, and became a self-proclaimed "modernity". Under this premise, all magnificent neoclassical buildings were constructed. These works mainly controlled, segmented, and finally assimilated the first inhabitants of the land that is what historians claim as "the style of colonial victory". The remains of this colonial building can be seen everywhere in Algeria, Vietnam. For example: the Mansard roof of the Alger Municipal Theater, the Bône and the Oran City Concils (Fig. 1) are taken directly from the model of Parisian urban architecture. The same was true of the Dakar Colonial Palace in 1907, the Ho Chi Minh City Government Theatre Hall and the Hanoi Opera House (Fig. 2). Colonials and visitors in the colony were still immersed in the memory of the European metropolis. Visiting Tunis City in 1906, British historian Douglas Sladen declared: "It is like Paris abroad" (Jones, 2014, p. 331). The same South African Durban City Council (Fig. 3) with English Baroque style was designed by Stanley Hudson. The colonial administrative center mainly reflects the image of the empire's prosperity and consolidates its political power as the center of the world. The dome is based on the architectural vocabulary of the Belfast City Council in Ireland, showing the empire style and the ambitions of the empire colonists in West Africa (Jones, 2014, pp. 330-331). 


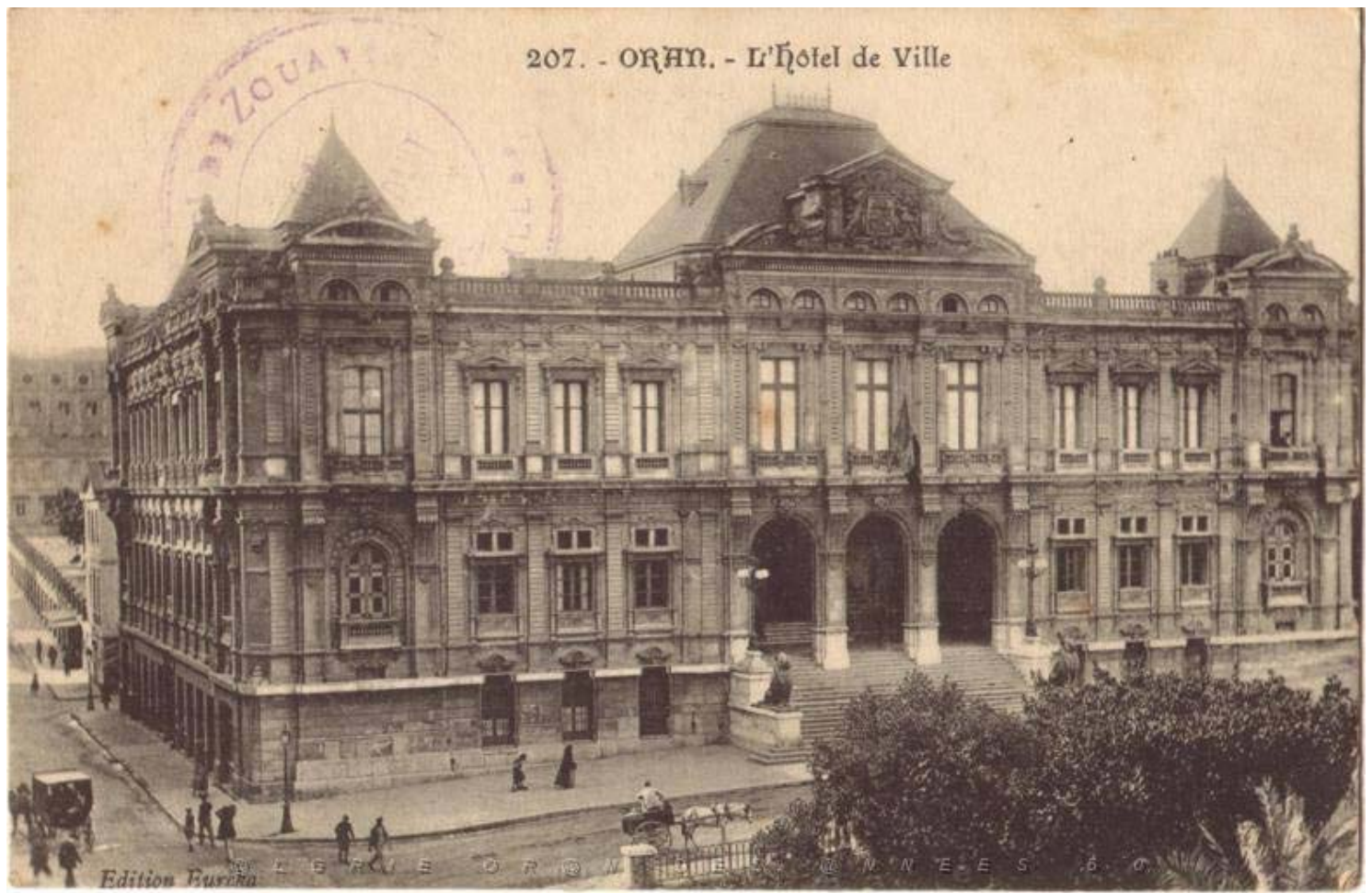

Figure 1. The Oran City Government taken from the Parisian style. Image source:

http://forgalus.free.fr/LE\%20COIN\%20DE\%20RENEE\%20BARTHES/ORAN\%20MES\%20CARTES\%20POSTALE S/slides/019\%20\%20SERIE\%20ORAN\%20\%20HOTEL\%20DE\%20VILLE\%20ANNEE\%201910.html.

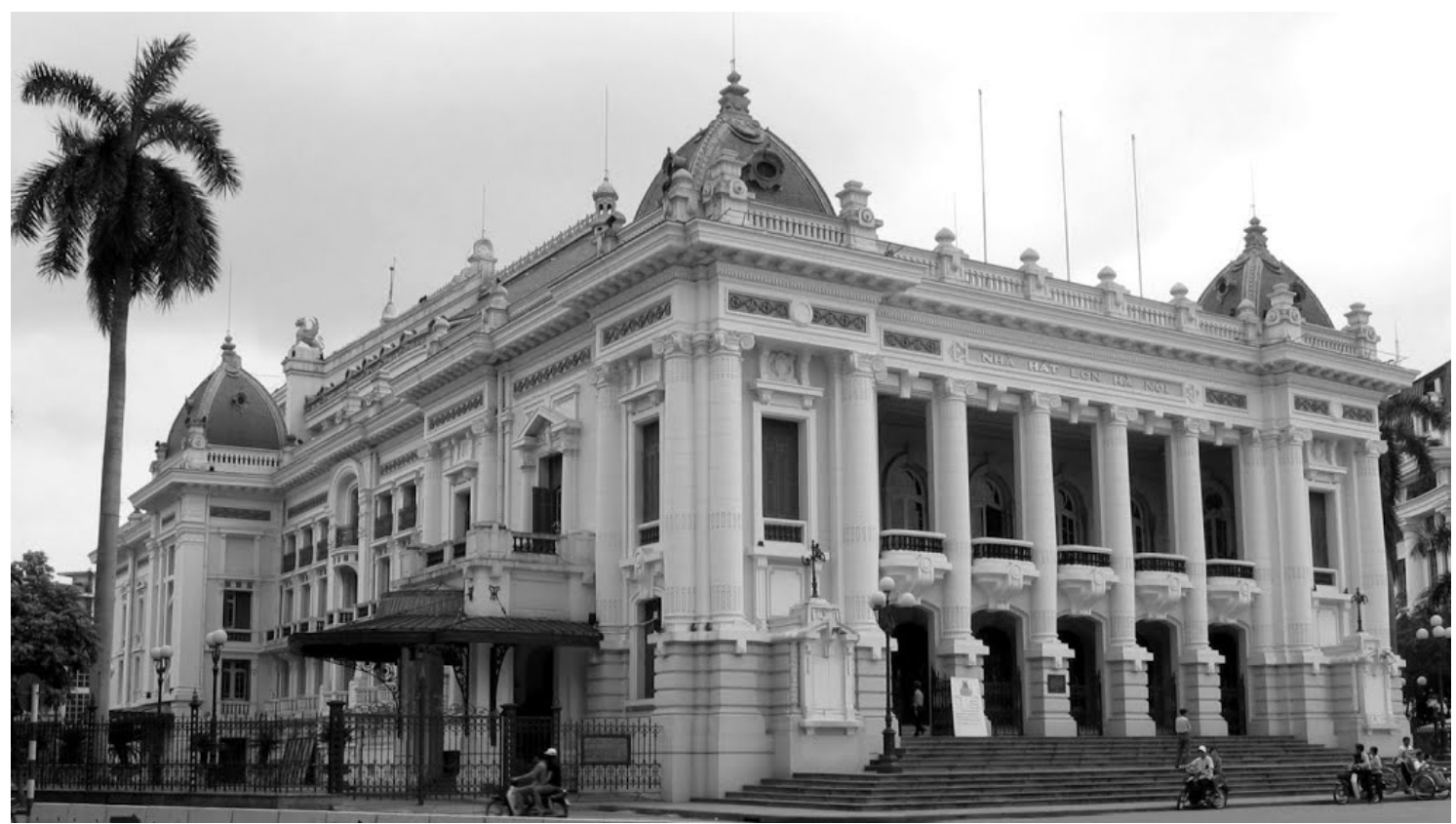

Figure 2. Hanoi Opera House, Vietnam, neoclassical style. Image source: https://ssl.panoramio.com/photo/110898303. 


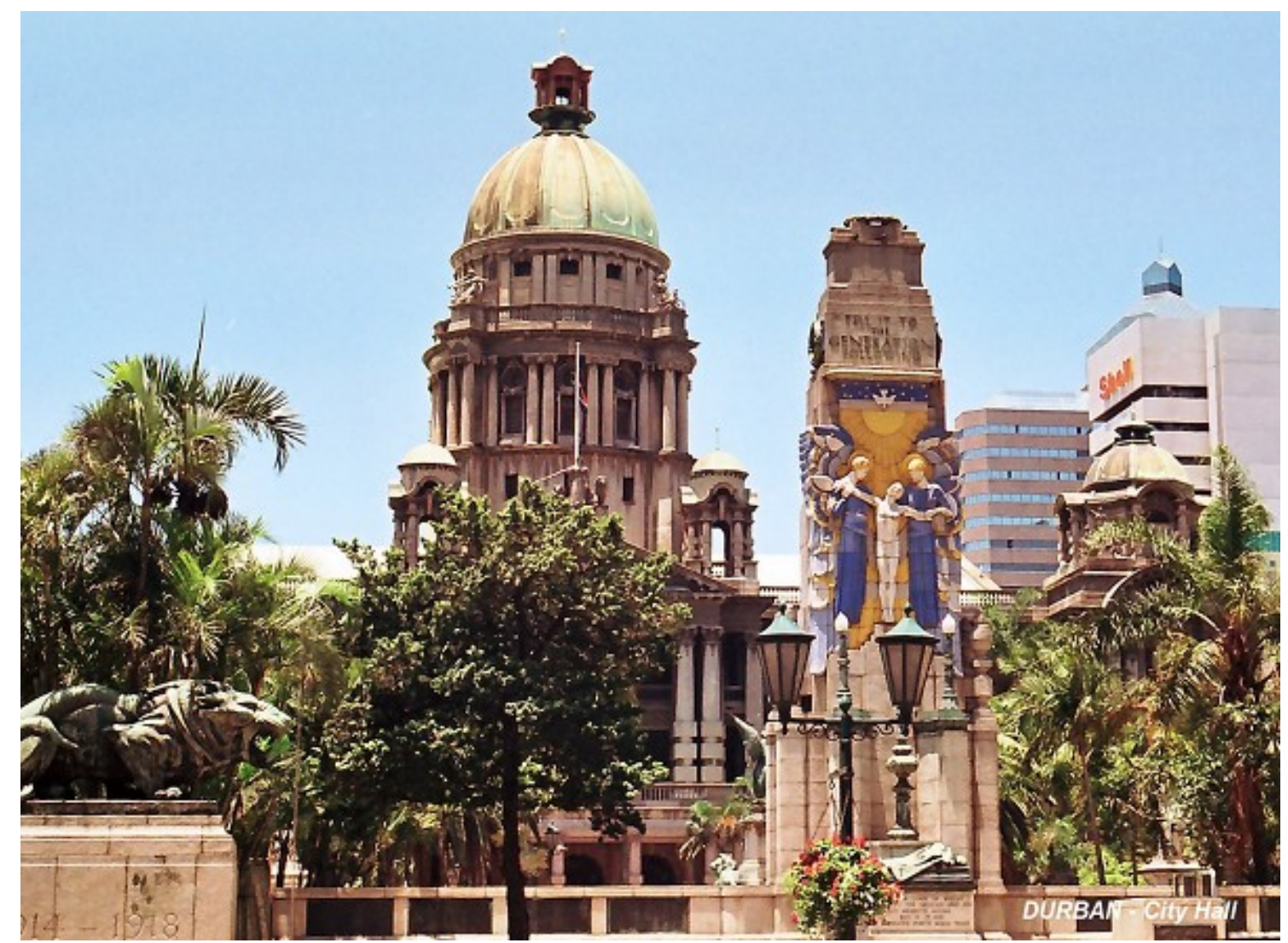

Figure 3. Durban City Government. Image source:

https://files1.structurae.de/files/photos/1927/afrique_du_sud/5019a_96.jpg.

\section{Japanese Modernization}

Japan began its first Sino-Japanese War victory in 1895, defeated in the Second World War in 1945, and formed a historical Japanese colonial empire in the middle of 50 years. In 1868, Emperor Meiji competed with the United States in Europe. The new government promoted a policy of rapid modernization. This was the era of great construction. The government encouraged architects to follow the European model teaching. The aim was to create a classical style and neo-Gothic style architecture that was comparable to Western countries. The first priority is how to integrate local technology into Western-style buildings. In addition, Japan's imperial expansionary politics has made the role of architecture show the complexity of the country and the empire. Not only do architects have to face a variety of different styles and technological choices, but also the expanding geography of the Empire. Most of the architectural projects were practiced in Tokyo and became a testimony of the times. The colonies also became fertile ground for practicing new styles. Around 1890, the university architects of new generation were born in Japan, replacing foreign construction experts in the UK, France, and Germany. The main purpose of the new generation of architects was to create a new style of administration, government institutions, and became a model for the colonies. Tokyo Bank (Fig. 4) designed by Tatsuno Kingo and the Akasaka Palace (Fig. 5) designed by Katayama Tōkuma are inspired by the neo-classical style. Both have large architectural proportions. We can see the main elements of classical architecture such as columns, gables, and railings, and reinforced concrete structures incorporate modern techniques. 


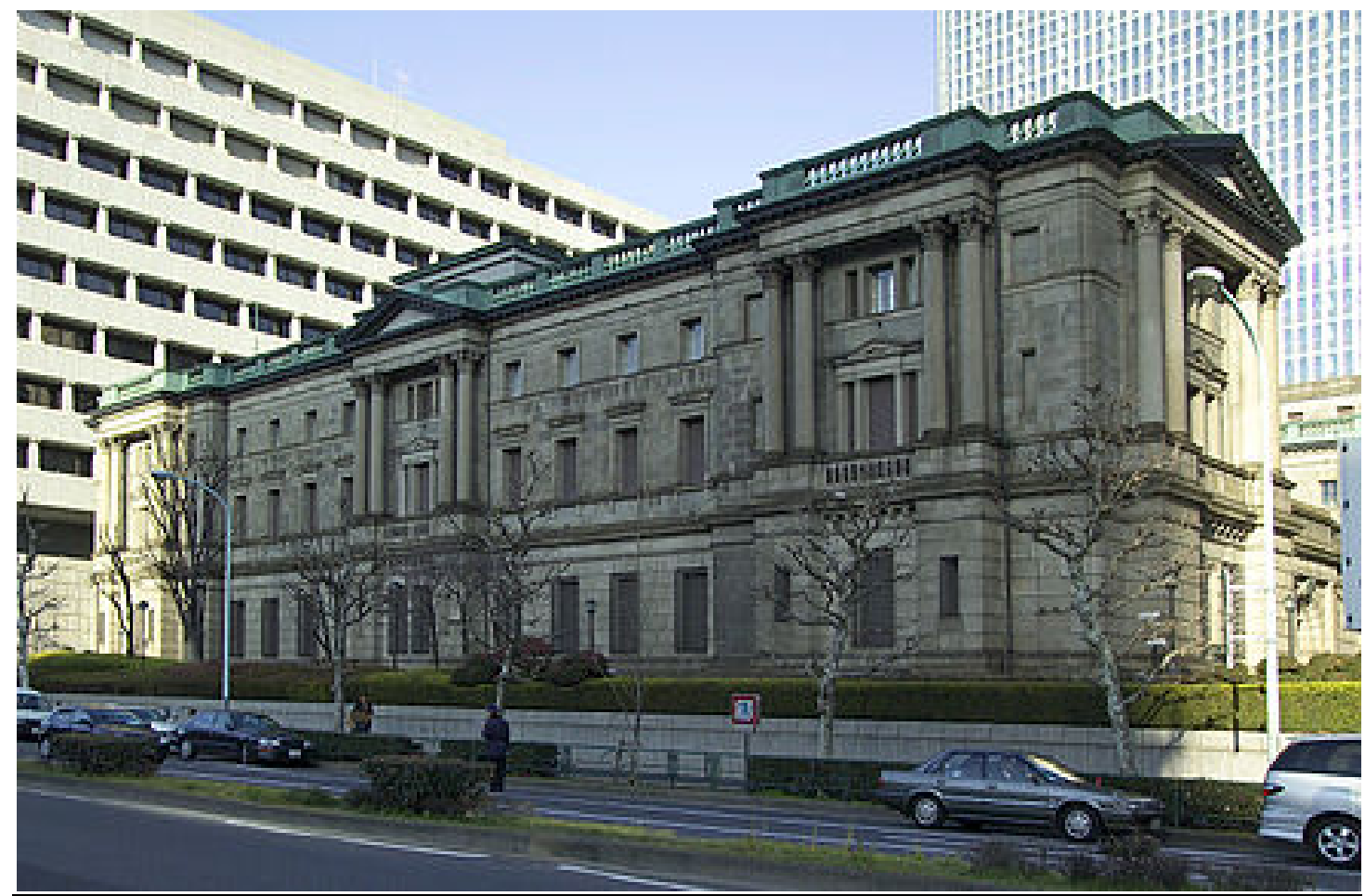

Figure 4. Bank of Japan building (Tokyo), designed by Tatsuno Kingo. Image source: http://www.wikiwand.com/en/Tatsuno_Kingo.

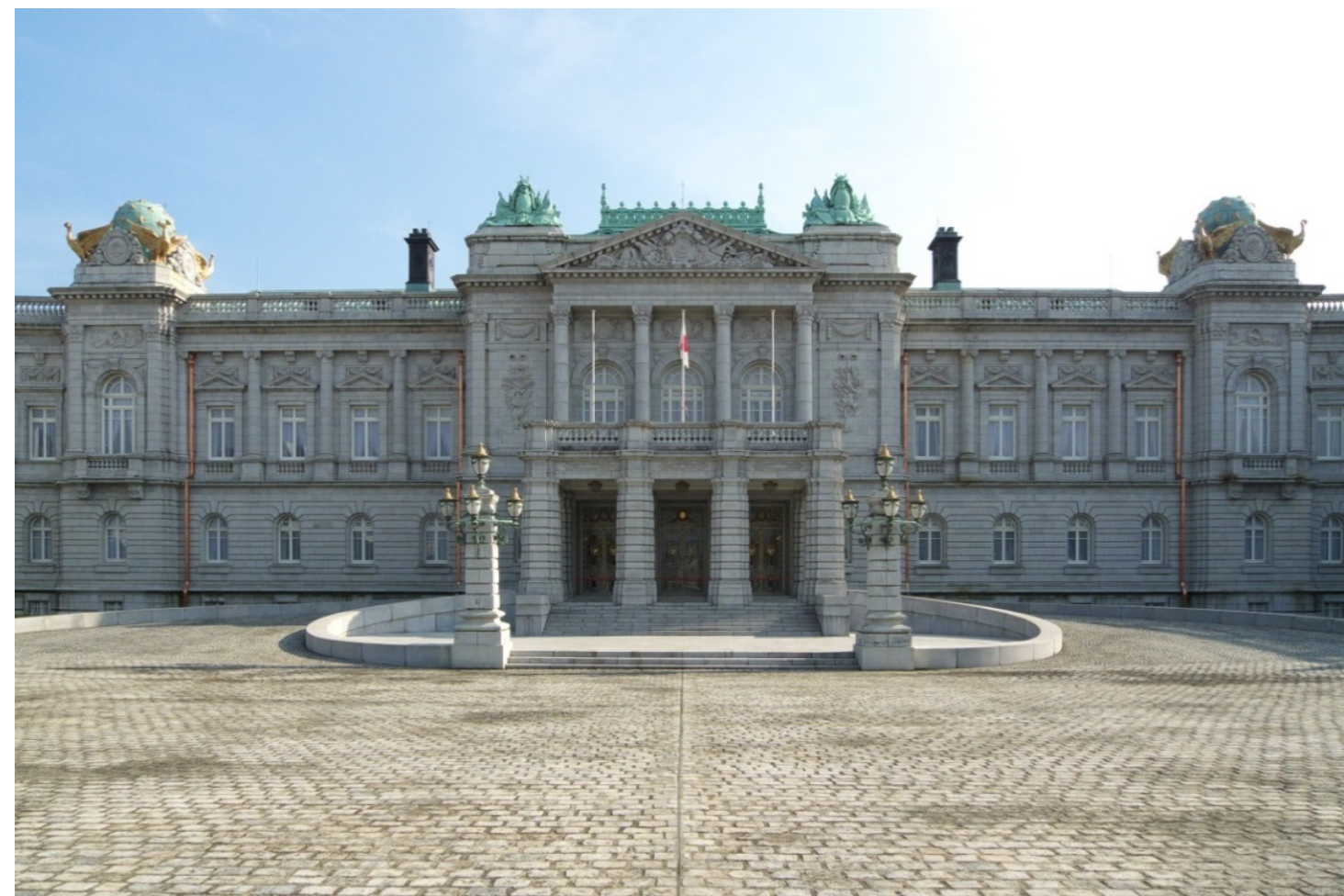

Figure 5. Akasaka Palace designed by Katayama Tōkuma. Image source:

http://www.wikiwand.com/fr/Palais_d\%27Akasaka. 
Through the encouragement of the government, they collected, classified, and visited the style of the shrine and the ancient temple to analyze the influence of traditional elements on the visual and symbolic effects of modern sketch design. The commemorative Imperial Temple and the Japanese Palace of the World Exposition showed the characteristics of the country. Due to professional skills, craftsmen, architects, and architectural historians formed a special Japanese style re-creation. Between 1890 and 1930 this pre-modern architectural style began with one-sidedness and was found in most projects. Japan's imperial crown building ${ }^{2}$ used in offices, banks, hotels, museums, and reinforced concrete, represented a mixed culture.

\section{Taiwan's New Construction During the Japanese Rule Period}

According to the "Introduction" of Yuko Kikuchi's Refracted Modernity: Visual Culture and Identity in Colonial Taiwan (2007), during the Japanese rule period, Taiwan's basic urban-rural structure began to undergo social and political changes. Between 1895 and 1945, the Japanese colonial government enforced a modern policy and plan in Taiwan. At this time, Taiwan accepted Japanese education, customs, culture, and especially from the westernization of Europe. Therefore, the Japanese society was modernized, and Taiwan was advancing at the same time. In the part of architecture, from a colonial point of view, various Western historical styles and Japanese modern styles have become the standard vocabulary of Taiwanese architecture, expressing modern concepts.

Taiwan as a Japan colony, where Japan planted massive sugar, tea, and bananas, as well as a variety of industrial products, mainly supplied for the needs of the colonizing power, Japan. There are diverse national modernization plans to create modern technology and social systems. Railways, highways, bridges, and ports were built; irrigation system, tap water, and underground water system also began to set; the electrical system at this time also began to establish, including industry, banks, hospitals, schools, research centers, and museums. The colonial government also performed many of the scientific programs, such as: land survey, museum's collection information survey, tropical medical research studies, and anthropology (especially indigenous ethnic language with culture) (Kikuchi, 2007, pp. 3-4).

According to Fu Chao-Ching's article: "Taiwaneseness in Japanese Period architecture in Taiwan" (2007), during the five decades of Taiwan under Japanese rules, the colonialist, Japan in Taiwan planed and built modern cities. Japan hired British urban designers to design the modern metropolis of Taipei. For example: The implementation of the Walls of Taipei Correction Plan began with the appointment of W. K. Burton, a health engineering consultant technician, to engage in the modernization of cities in Taiwan the Taiwanese city (Huang, 1999, p. 8), with Western Europe as model, and those modern cities also showed the authority of colonial government, often referring to as a scientific transformation of Taiwan. For Japan, the colonialist, Taiwan just as a colonial template, in China, Japan, and Taiwan triangular relationship, Japan in the past felt lower than Chinese culture and Western European culture, but in the Meiji Restoration, it ranked the first in Asia catching up with Europe, so Japan was looking forward to Taiwan as a imaginable political body, and to be a model and sample of Japanese colonial empire; under such a policy, Taiwan has gone through a process of westernization and modernization, so that urban and rural acceptance of modern baptism. This new western style is different from the houses, temples, markets in past Qing Dynasty. New style and new function combined with Japanese-style house; the construction of modern buildings began in the 20th century, such as

\footnotetext{
${ }^{2}$ Imperial Crown building: A modern building built with modern reinforced concrete structures and combined with traditional Japanese styling; it belongs to the generalized Japan and western eclectic architectural genre.
} 
schools, museums, post offices, hospitals, railway stations, cinemas, and parks. These public buildings began to change the landscape of Taiwan, to some extent and also took Taiwan away from the identity of Qing Dynasty and biased a part of Japanese westernization movement.

In the process of such assimilation, new buildings became involved in the modernization process; modern cities have shaped the different daily life styles of the Taiwanese people, rich and varied. New public buildings in Taiwan under Japanese rule in particular, showed a variety of different differences. These new forms of public buildings were not only expressed in aesthetics with art, but also with political implications.

Japan's professional architects took Taiwan as an experimental area of Western history style, and new technical architecture. It was very popular in the Meiji period, probably in 1868, to some extent these methods were very avant-garde. For whole Asia, the technology was very advanced. In 1909, Taipei had the first telephone exchange, and at the time also became a fashion of modernization symbol. Because of the Japanese homesickness, a lot of shrines were also built. The modernization style was popular in the West in 1930, and was also brought to Taiwan by Japanese architects, becoming a symbol of technological progress. For the people of Taiwan, those Western historical-style buildings brought a new visual experience, especially in the urban landscape design, such as central towers, dome, round columns, symmetrical facades, and monumental colonnades brought new weather. There were also large squares, and Mansard roof style, bringing new architectural elements, which was never seen before; therefore, with these buildings, Japanese government created a new the authority and urban landscapes (Fu, 2007, pp. 172-178).

Japanese colonial expansion launched a new vision of architects. The Governor-General's Office in Taiwan under Japanese rule was the highest administrative building in Japan. The central tower, with red bricks and white horizontal friezes, was about 60 meters high. It was the tallest building in Taipei at the time, and the most modern building in Taiwan under Japanese rule (Jones, 2014, pp. 342-343). The building was open for design competition. Originally, the first Kichibei Suzuki's work was questioned similar to the Dutch International Court of Justice in The Hague, and changed to second place Uheiji Nagano's work. In order to meet the needs of the office space of the General-Governor's Office, Mr. Matsunosuke Moriyama, who was the Governor's staff, an engineer at building and repairing section of the Taiwan Government-General, was requested to make changes to his fourth-place work.

Imagined communities-southland, exotic. Modernization and cultural consciousness at that time brought an imagined community; from the edge of a China, Taiwan was defined as an independent body of culture, having its own unique characteristics, while the ethnic and cultural identity with Taiwan also had been established in this period, so there was an imagined modern state. In addition, Taiwan's culture images were shaped exotic, but also recognized as a primitive wasteland, full of infectious diseases, and the customs of the aboriginal head-hunting. During the Japaneseization process, Taiwan's image was transformed into a romantic southland style, just as the Northern Europe loves Italy in the Southern Europe, so Taiwan has become a southern scenery built in the colony (Kikuchi, 2007, p. 4).

Colonial segments and class. In such buildings, especially the Taiwan Governor-General's Residence, it has colonized segment and class distinction, while like immigration village, drawing geographical boundaries to segment with Japanese. In the part of class, in which three grades were established, the nationals of mother country, Japan as the first, the Han nationality of Taiwan Islanders as the second, and the aborigines as the third, having different policies. Taiwan Governor-General's Residence was the mansion of class nature, with official colors and receiving foreign dignitaries. In the building space, it was divided into master and servant areas, but 
also a residence for Japan's high society, royal family, and the nobility, so with a strong color in Western Europe, in which there are billiards, Western decor, rare room, and French-style garden layout, becoming a new style and model.

This part also shows the Japanese colonial policy toward Taiwan is different from European and American colonial policies toward Central and South America. Not like the general hostility toward Chinese mainland, Japan expected Taiwan becomes its economic warehouse, and various sources of sucrose, camphor, and timber. She implemented a policy of assimilation, such as Japanese education, language, and religion, expecting Taiwan to become a province of Japan; however, there were still segments of the people, and therefore fundamentally different.

\section{The Historical Context of Taiwan Governor-General's Residence}

\section{Taiwan Governor-General's Residence and Walls of Taipei Reconstruction Plan}

Walls of Taipei reconstruction plan. In the early days of the Japanese rule of Taiwan, the various buildings left by the Qing Dynasty were used excessively. In order to effectively rule, the Japanese quickly changed the original administrative area of the Qing Dynasty, demarcated a new administrative district, and launched a new construction that surroundings were completely different from the former. At first, the Japanese colonial government's attitude toward the urban environment began with a health perspective. In the 25th year of Guangxu, Qing Dynasty (1899, the 32nd year of Meiji), the Government-General of Taiwan promulgated the "Taiwan Sewer Rules" to look forward to the unified city and street waterway facilities to maintain sanitary quality. In the 26th year of Guangxu, Qing Dynasty (1900, the 33rd year of Meiji), Government-General of Taiwan further promulgated the "Taiwan House Building Rules" and announced the implementation rules seven years later. The key point is that the construction of the new building must be approved, and the government is authorized to dismantle the bad building (Liu, Kao, Fu, \& Hsiao, 2009, p. 277).

At that time, the construction of the Taiwan Governor-General's Residence was related to the dismantling of the Walls of Taipei. Because of the large amount of stone required, the stone of the city wall directly became the foundation of the Governor-General's residence. In addition, the setting of the Taiwan Governor-General's Residence started and ended at the same time as the Taiwan Shrine. This part is the famous imperial road, which is directly from Zhongshan North Road to Yuanshan. It represents the highest power of the Government-General of Taiwan to rule Taiwan. The Taiwan shrine represents the belief of the Japanese Emperor, and therefore serves as a hub for Taiwan.

Taiwan under Japanese rule in 1908 (the 40th year of Meiji) is a brand-new era for Taiwan. The Western railway runs through the whole railway line, the distance between towns is shortened, and various architectural trends and styles are spread faster. The urban correction of each city was also fully launched in 1910. The wide streets made the new buildings match the urban development. Together with the Japanese technicians who have acquired the expertise of Western architecture, they came to Taiwan to make the development of the building grow rapidly. During the booming period of 1910 and 1920, the majority of Western historical buildings accounted for the most. The designers of this period were mostly professional architects who were rigorously Western-oriented architectural education. These architects' design followed the elements of Western historical architecture, thus presenting a model of character (Liu, Kao, Fu, \& Hsiao, 2009, p. 277).

These Western architectural styles can be summarized into two main sources. One is the historical style from the European continent, including the Renaissance style, Baroque style, imitation of Roman style, 
simplified Goethe style, Mansard style, and neo-classical style, etc.; the second is from the Victorian England brick building in the UK, including the red brick free classical style (or Tatsuno Kingo style), red brick arcade style, and so on. The first type of building is more rigorous in style.

The way in which elements are taken and organized is usually in accordance with Western standards; the second type of building is relatively free, so it is quite lively and diverse in style (Liu, Kao, Fu, \& Hsiao, 2009, p. 280).

Historical context. In 1899, Kodama Gentaro advocated the Western style of the gorgeous Taiwan Governor-General's Residence to convince the Taiwanese. The Governor-General's residence completed in 1901 (the 34th year of Meiji), according to the chief of Civil Engineering Division of Government-General of Taiwan, Nagao Hanpei's memory:

When the Governor-General's residence rebuilt, it was said, if do it subject to Gato Shinpei, we do not know how much budgets will be needed, and what kind of building will be constructed. Goto Shinpei heard such criticism, and said, Taiwan Governor-General is the premier position of our country to operate the South, so his official residence should be perfect, and in which I originally wanted to set up an exclusive theater, but considering the prevailing circumstances and gave up; people who criticized official residence did not understand the situation of my country to operate the South. (Huang, 2004, p. 44)

In addition, according to the technician of Civil Engineering Division, Ishikawa Kentaro's memory, Governor-General Kodama Gentaro used the Accounting Act to circulate the Taiwan Jinjia architecture works remaining funds for Governor-General's residence. Considering Governor-General's residence as a symbol of the ruling class of Japanese colony, so they built it with desired grand style as could as possible (Huang, 2004, p. 44).

Governor-General and architects. Kodama Gentaro, the 4th Governor-General of Taiwan under Japanese rule, took the office on February 26, 1898 (the 31st year of Meiji), appointing Gato Shinpei as the director of Bureau of Civil Affairs (later renamed as Civil Affairs Executive). Because he was not often at Taiwan, he commissioned Gatoto to handle the complete Taiwan government affairs, forming the "Kodama Gato System". They promoted Taiwan's old habit survey, wantonly engaged in iron, road construction, pier construction, land survey, as well as camphor, salt, and tobacco monopoly, and cultivated Taiwan's sugar industry (Lin, 2009, p. 28).

Who is responsible for the design of the new project for Taiwan Governor-General's Residence? There were no clear records shown in historical materials. However, according to the memories of some technicians who were active in Taiwan during the Japanese occupation, it was designed by Togo Fukuda, Satoshi Miyao, and Ichiro Nomura. Among them, Togo Fukuda, former Army Manager and Technician, and the chief of building and repairing section, Civil Engineering Burau of the Taiwan Government-General, should be the main designer. The designer of the Taiwan Governor-General's Residence, Togo Fukuda graduated from Department Civil Engineering, Engineering College of the Imperial University. During his schooling, Josiah Conder was serving in Home-Making Department (later Department of Architecture, Tokyo Imperial University) as a teacher; Togo Fukuda possibly elected the Conder's courses, or also for his personal interest in the architecture, in which has dabbled. In short, to view his experience being responsible for the design and supervision over the construction work everywhere, Togo Fukuda should have been able to grasp the use of architectural style. Taiwan Governor-General's Residence was started construction on April 1989 (the 32nd year of Meiji), so the architectural design should have already completed one year ago, the same year when 
Akasaka Palace designed by Katayama Tokuma was completed. Togo Fukuda's design uses the New Renaissance style, which is consistent with the awareness of Conder and Katayama Tokuma on architectural style. In fact, the composition, and ratio in the New Renaissance style of Taiwan Governor-General's Residence can be regarded as correct, and because not symmetrical, it increased the official residence building with fantastic, free, and romantic atmosphere. Moreover, Taiwan Governor-General's Residence has a balcony on all sides. It is influenced by the colonial style of the balcony. It is similar to the architectural styles of Southeast Asia colonized by Europe and the United States. It is a combination of balcony colonial style and Renaissance style. It has the symbolic meaning of colonization in Taiwan (Lin, 2009, p. 48).

The background of his origin can be found by Satoshi Miyao's personal resume. Satoshi Miyao was from the Shizhoku of Kochi Prefecture, born on April 24, 1984 (the 1st year of a gantry of Genji), and had received general basic education in his hometown of Kochi Prefecture since childhood. The background of his architectural education is very strange, from November 1886 (the 19th year of Meiji) to February 1889 (the 22nd year of Meiji); his architecture study was taught by Dr. Hanroku Yamaguchi, a construction engineer, and Hattori Jungoro, a construction technician, instead of entering any school building-related school. Satoshi Miyao learned such subjects as "General Architecture", "Material Theory", "Construction Theory", "Architectural History", "Artistic Ideas", "Cartography", "Design”, and "Formula”, from Hanroku Yamaguchi, and the "Japanese Architecture Studies" from Hattori Jungoro.

Hanroku Yamaguchi, the architectural enlightenment teacher of Satoshi Miyao is one of the few French architects in Japan's first generation of architects. Hanroku Yamaguchi studied at L'Ecole Centrale des Arts et Manufactures. The architectural education received is municipal-related legal, political, economic, and public facilities and buildings required for the life of citizens such as water supply and drainage channels, waterways, town halls, hospitals, schools, and residences, rather than the palace architecture education representing the country, and the aristocratic (Huang, 1999, p. 28).

After the residence was completed, the roof was invaded by termite pests and was seriously damaged. Until the 43rd year of Meiji (1910), Taiwan Governor-General's Residence had several large and small renovations. In the first year of Taisho (1912), it had undergone a major renovation, i.e., the space that was not functional was adjusted. The project was undertaken by Matsunosuke Moriyama and Shigasuke Hachiban.

\section{Architectural Style and Spatial Configuration}

The Taiwan Governor-General's Residence during the Japanese rule period is located within the street blocks surrounded by Bunbu Cho, Akashi Cho, Higashimon Cho, and Asahi Cho, which is now the Ketagalan Boulevard, Gongyuan Rd., Zhongshan S. Rd., and Changde St., Taipei City. The main entrance of the residence was located in the southwest corner; the building was facing south, and there was a courtyard in front and a garden in the back. At the time of initial construction, there was only a low wall, and then a closed wall is gradually formed, and a Bunker-style concierge (guardhouse) was set at the main entrance. The two-story building without completely symmetrical spaces and contours but was still the product of the Ecole de Beaux Art system.

Taiwan Governor-General's Residence was competed on September 26, 1901 (the 34th year of Meiji), and its space is basically a cross-shaped intermediate space, separated east and west wings and the north and south sides, plus a distinction on the first floor and the second floor, so that each floor, each wing, and each side are configured with different functional space. In fact, the Governor-General's residence in the initial design of the 
new program already has three functions as Governor-General and his family living, Governor-General's administrative office on weekdays, and a social space to receive guests.

Overall, Taiwan Governor-General's Residence in Taipei has an entrance to the south, but all the important spaces are facing north. In fact, this space configuration concept is similar to many famous European palaces. The important space is located at the back of the entrance and is integrated with the garden. The people in the important space can enjoy the beauty of the garden. The Palace of Versailles in France can be described as the king of the palace. The relationship between the mirror hall and the garden is the same. The design trend of the Taiwan Governor-General's Residence in Taipei originated from the French art system. It is not surprising that its spatial organization and configuration concept is similar to that of a French palace.

From the perspective of the styling, Taiwan Governor-General's Residence in Taipei can still be said to be the style of the French Academy of Arts. The combination of classical architecture and elements is its greatest principle. The entire building of the Taiwan Governor-General's Residence in Taipei is obviously made up of base (the house body) and roof. Base is built of heavy stone, with ventilation holes at every interval. There is a bottle railing at the edge of the outer gallery, and a large staircase between the base and the garden in the north. A traditional stone lion stands on the railing of the ladder (removed from the Taipei Mazu Temple). The two-layer house can be divided into an entrance porch, a corner tower, and a main body. For the outer gallery of the main body, the first layer is basically treated by an arch ring, and the imitation stone is horizontally connected to each other by arching stone moldings. Most of the façades on the second floor are in the form of single columns, but after the renovation, the combination of the pair of columns was adopted. The column type is the deformation of the Ionic column in the West, and the truss on the column has a pendant decoration. The performance of such pairs of classical columns was actually the way that the architecture of Ecole de Beaux Art often used. In addition to a few cases and a few buildings that Matsuzaka Moriyama participated in, such as the Government-General of Taiwan and the Taipei official buildings, this was a rare element in Taiwan.

In the Western historical style, the Mansard style is an architectural style popular in the Second Empire of France. Its main feature is the symmetrical body composition, with a prominent central body and a supporting roof. The Masa roof is also a registered trademark. The roof of the roof is often open with bull's eye windows and tiger windows.

In the Western historical style, the Mansard style is an architectural style popular in the French Second Empire. Its main feature is the symmetrical mass, with a prominent central body and a supportive eaves. Mansard is also its registered trademark; the bull's eye and the roof window are often opened in the attic. Due to its strong commemoration, the Mansard style is also widely used in official buildings. The roof of the Taiwan Governor-General's Residence in Taipei, in addition to the turret, is basically a combination of Mansard and can therefore be classified as a Mansard style. If you look closely the Taiwan Governor-General's Residence in Taipei, the part of the Mansard roof is the mass at the central entrance and the $L$-shaped mass behind it, while other roof forms are used in the southwest turret and the southeast turret to make the building more asymmetrical. There are four pilasters on the second floor above the entrance porch to prop up the gables. There are medals and flowers in the gables. Above the gables is a Mansard combination with central straight edge, and bell edges of both sides. There is a roof window in the center, and bottle decoration in the corner. The $\mathrm{L}$-shaped Mansard tops are straight edges, and also have bull's eye and roof window. The top floor of the southeast corner is a usable loft, the roof is a curved pyramid roof, and wood-framed concrete scaffoldings are 
at the north and south sides; the southwest turret is a dome. Overall, the roof plays a very important role in the Taiwan Governor-General's Residence in Taipei, making its French classical image more intense.

The Office of the President in Taipei is the Government-General of Taiwan during the Japanese rule. It was completed in the 8th year of the Taisho period (1919), together with the Taipei Governor's official residence in front of it showing the nature of the Governor's Palace. The Government-General of Taiwan adopts the Tatsuno Kingo style that was popular in the Victorian brick building style of the United Kingdom. In contrast, the Taiwan Governor-General's Residence uses the vocabulary of the European Court building (Fu, 2009, pp. 184-191).

Renaissance style (Fig. 6, Fig. 7) floor plan (Fig. 9). Entire East Wing on the ground floor belongs to the space of office and transactional nature. On the south side, a "drawing room" was arranged, as a guest waiting place, next to the secretary room, adjutant room, and clerk room of Governor-General, so there were security personnel. On the north side, there was a large conference room (Fig. 11) with its subsidiary "drawing room", belonging to office administration. The west side is a part of the nature of the reception space. A "Guest Room" is the main social space to receive visitors, and "Large Dining Hall" (Fig. 12), is where large banquets can be held arranged on the north side. The Governor-General may go directly to the second floor by the stairs into the Guest Room (Fig. 13) to receive visitors, and talk with visitors, and then enter the Large Dining Hall for dining. Table manners are European type (Fig. 22); the south side is the space for kitchen, pantry room, and preparation rooms where servants, workers, and cooks access for service, plus such reception space as the "entranceway" (porch) entered from gate, entrance hall, "reception", and "waiting area", as well as Hat Room, and "night duty room" (night watchman room). The ground floor of Governor-General's residence completely belongs to the space of external nature. In addition, the southeast corner is configured with a unique "game room", within which there is pool table set like in European or Japanese mansion, where is a social living space of rest, entertainment, and chat for high society gentlemen after dinner. Thus, we can know the designer was familiar with social etiquette at the time.

Second floor for private space (Fig. 10). The second floor is private space; the rest room for Governor-General and his wife, and also a Comfort Room (Fig. 14), to place rare articles, which is a precious room in Europe for the upper-class visitors to browse rare artifacts, as well as a Lady Room specially to receive female friends. The south side of central "Hiroshima (hall)" (Fig. 15) is "Comfort Room" for living use and by the photographs at that time, we can find the porch of "Hiroshima (hall)" on the 2nd floor was carpeted, and placed with sofas, as well as displayed by pottery horses, screens, hanging scrolls, and ink paintings, mainly for parlor purposes; in the "Comfort Room", you can see the sofas and chairs, collected tea sets, drinking vessel, ornaments, treasures box, dolls, Japanese tabards, and bird specimens and the antiquities collection cabinet, mainly Japanese art collections. This space is a collection appreciation room of high society mansion, used for enthusiasts or guests to appreciate and enjoy, strongly showing occupants' class and taste. 


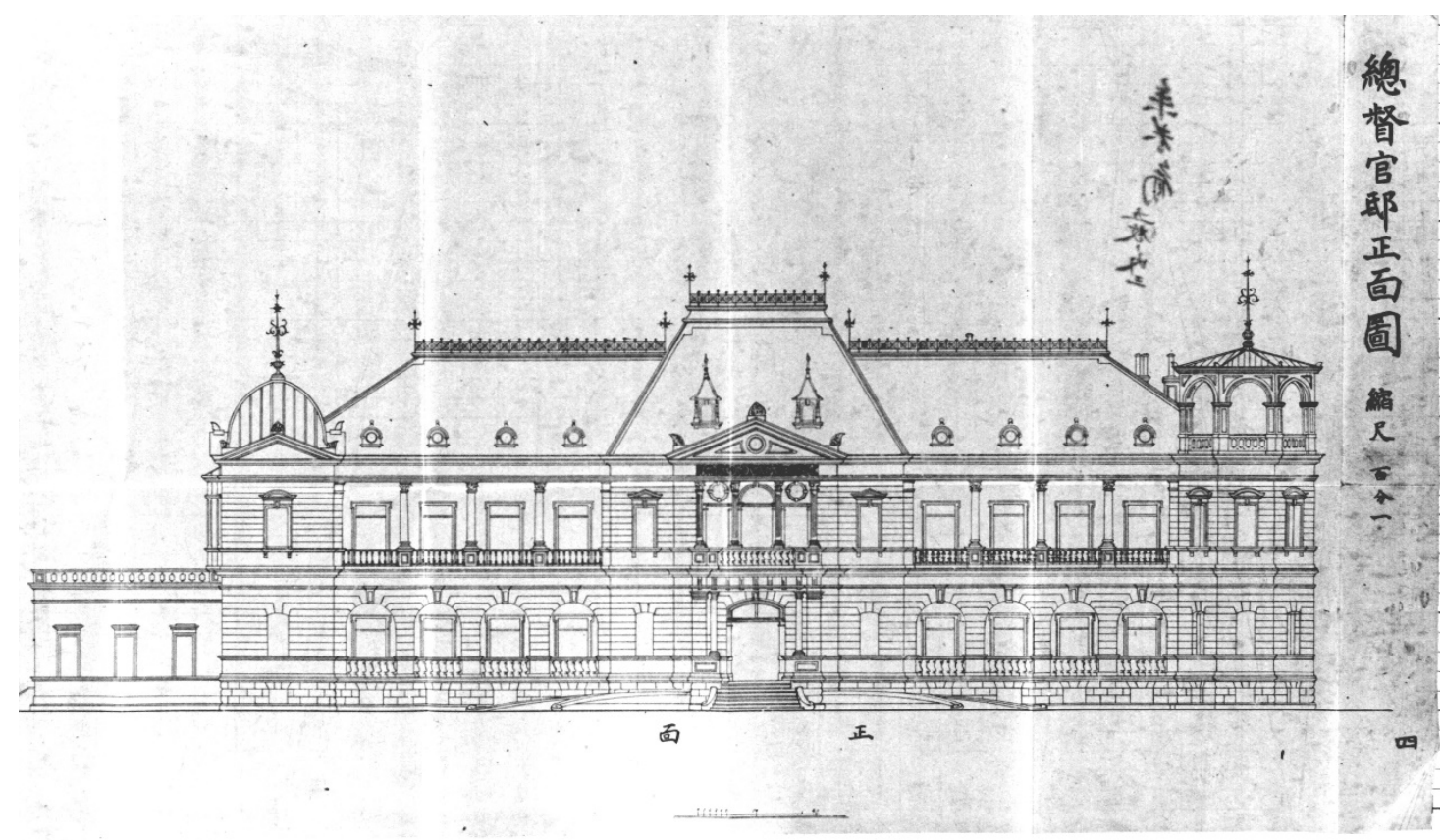

Figure 6. The south facade design of Governor-General's residence. Image source: Huang Chun-Ming, The Story of the Office of the Governor-General: The Office and the Residence of the Taiwan Governor-General, Taipei, Rikui Culture, 2004, p. 45.

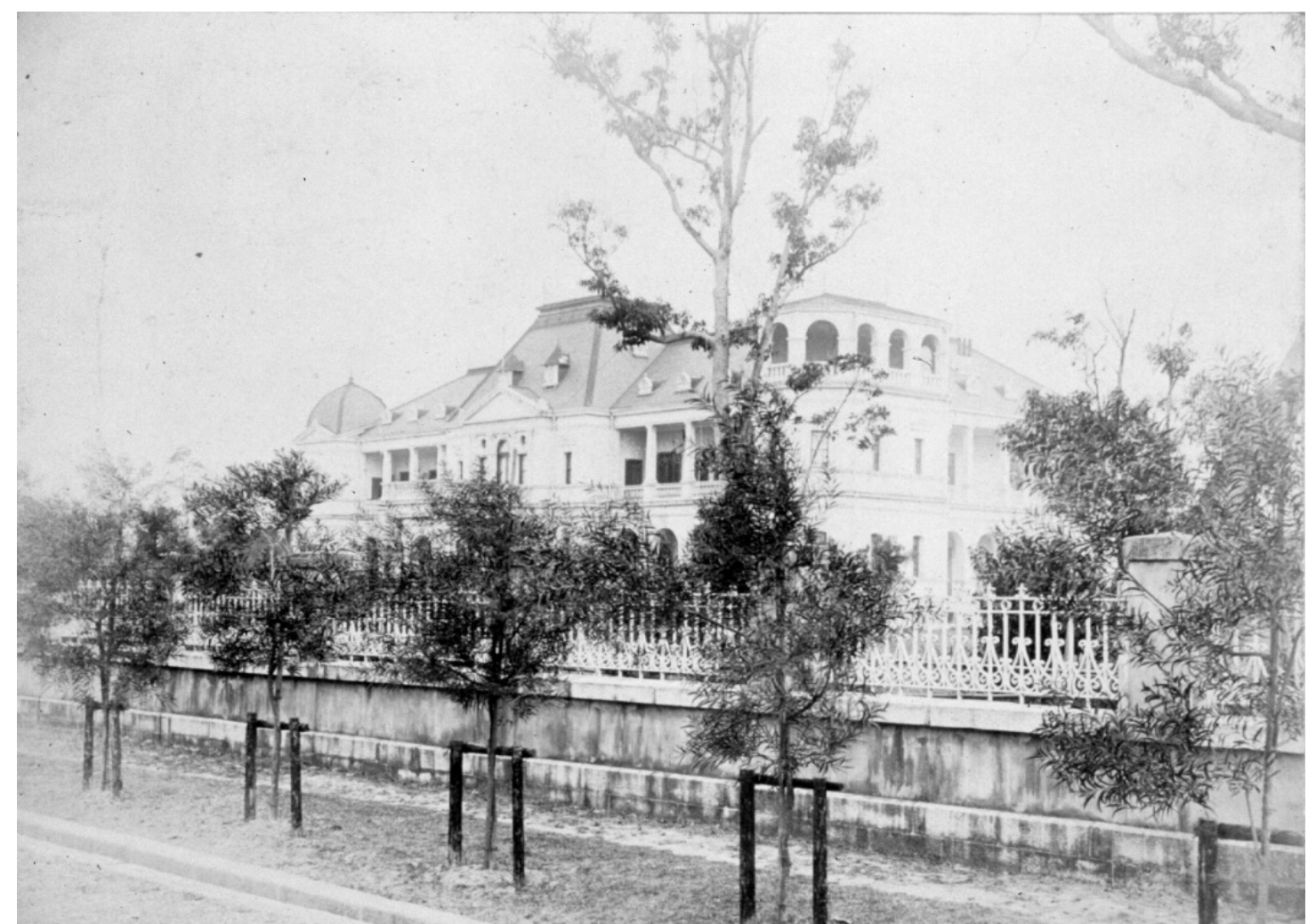

Figure 7. Governor-General's residence was designed by New Renaissance style, but no symmetry left and right, adding a touch of free and romantic atmosphere. Image source: Huang Chun-Ming, The Story of the Office of the Governor-General: The Office and the Residence of the Taiwan Governor-General, Taipei, Rikui Culture, 2004, p. 45. 


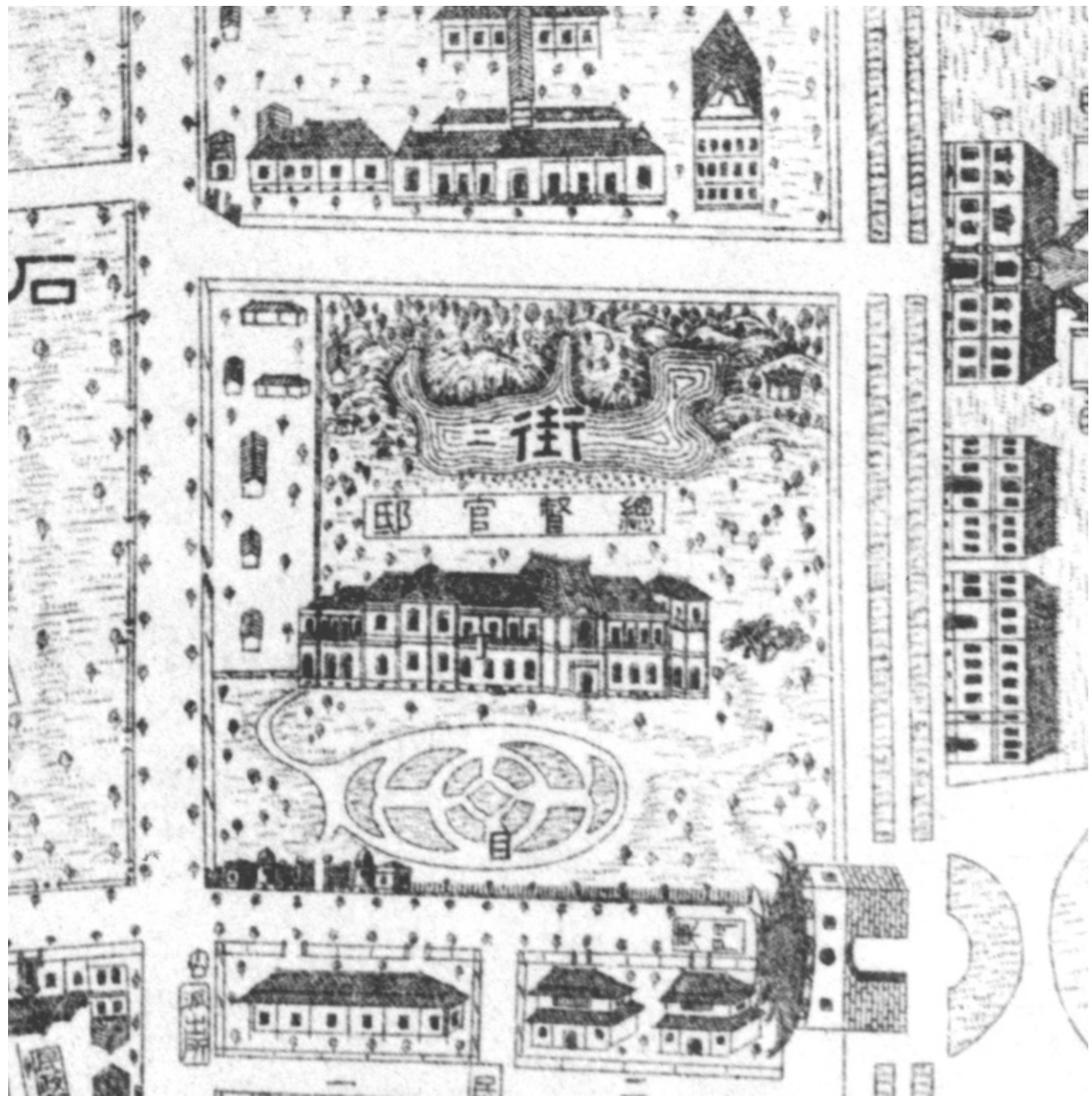

Figure 8. 1911 "Taipei Street Serial View" on which we can see the front and back gardens of the Governor-General's residence. Image source: Huang Chun-Ming, The Story of the Office of the Governor-General: The Office and the Residence of the Taiwan Governor-General, Taipei, Rikui Culture, 2004, p. 58. 


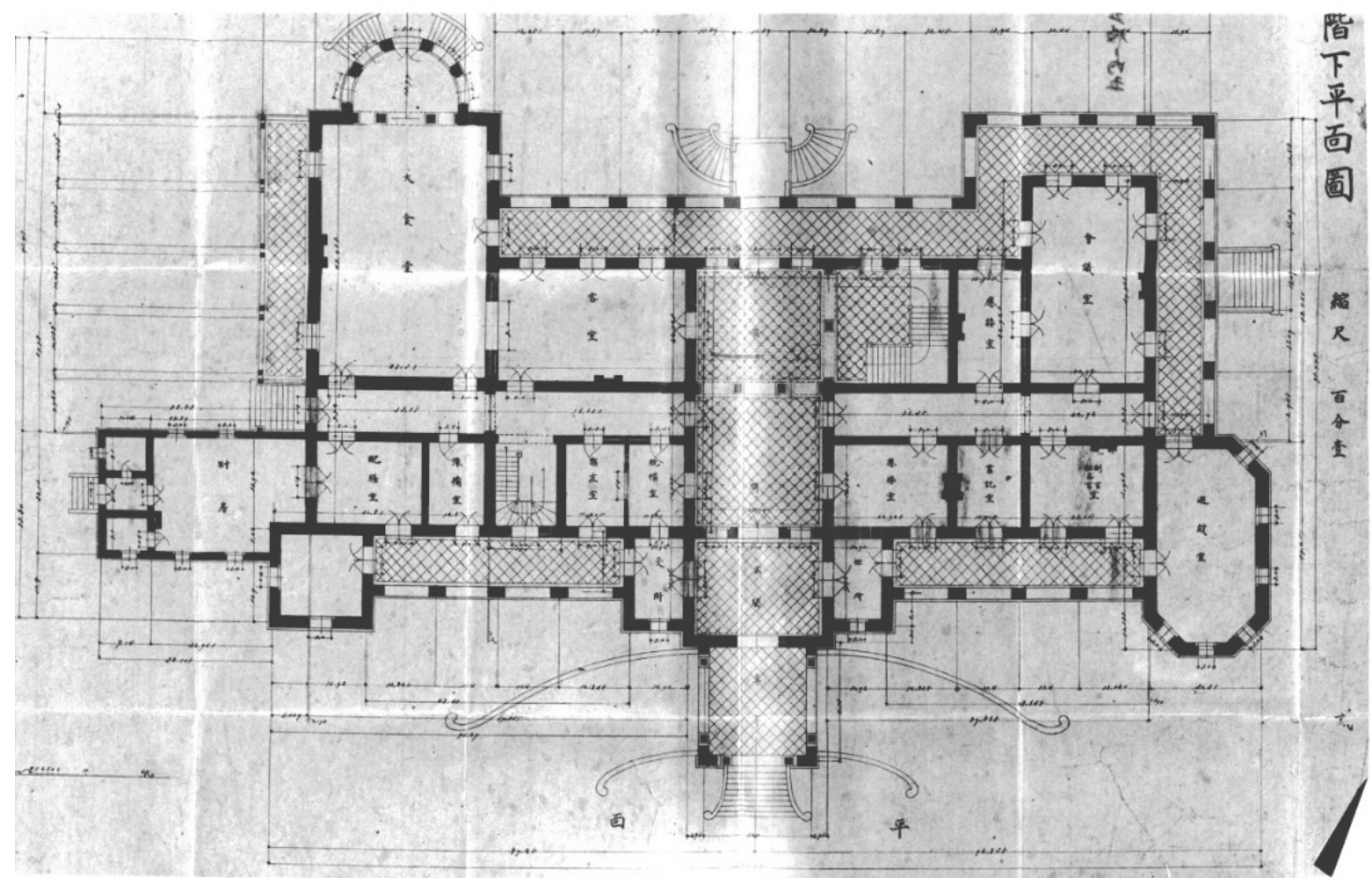

Figure 9. The ground floor graphic design of the Governor-General's residence. Image source: Huang Chun-Ming, The Story of the Office of the Governor-General: The Office and the Residence of the Taiwan Governor-General, Taipei, Rikui Culture, 2004, p. 52.

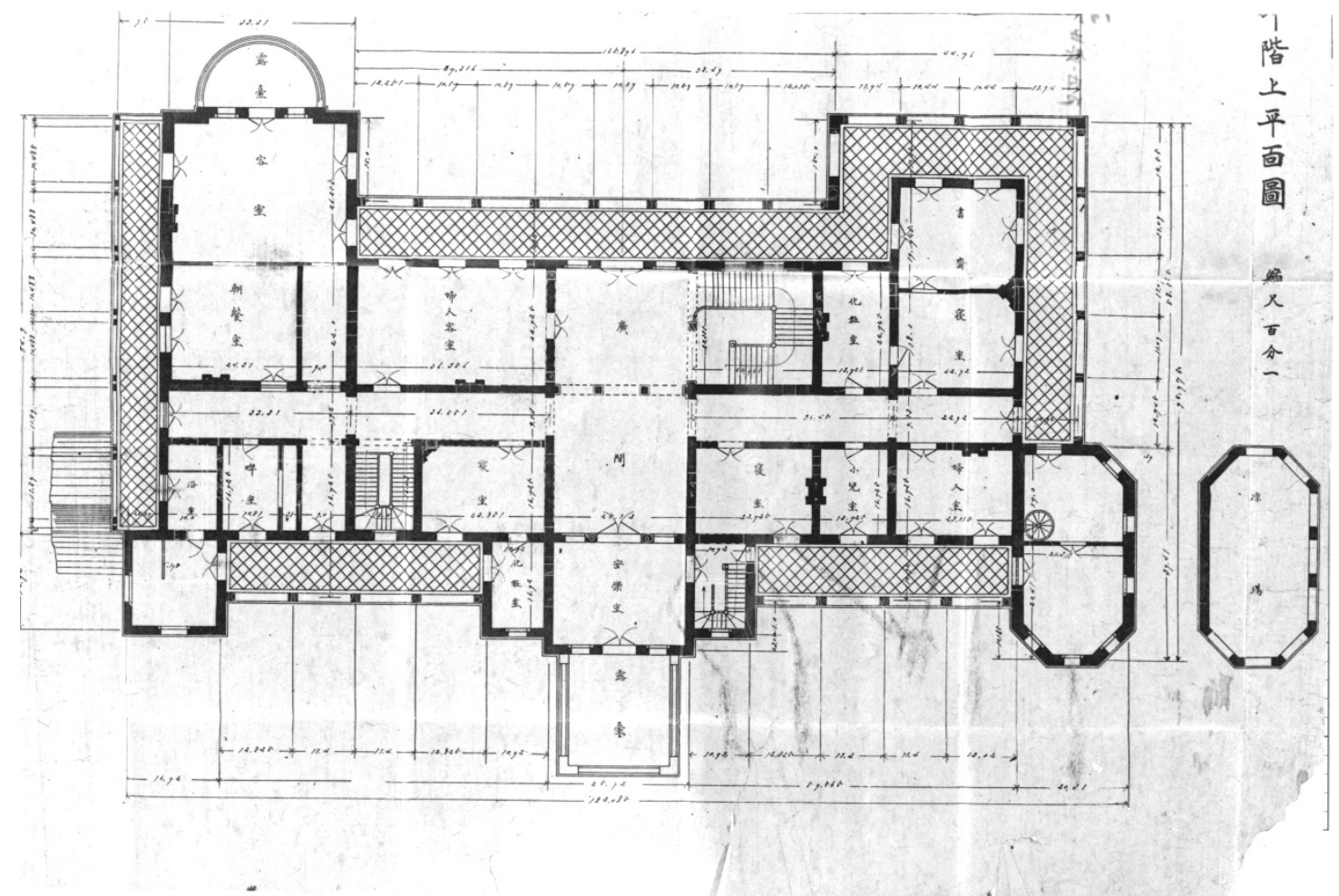

Figure 10. The ground floor graphic design of the Governor-General's residence. Image source: Huang Chun-Ming, The Story of the Office of the Governor-General: The Office and the Residence of the Taiwan Governor-General, Taipei, Rikui Culture, 2004, p. 55. 


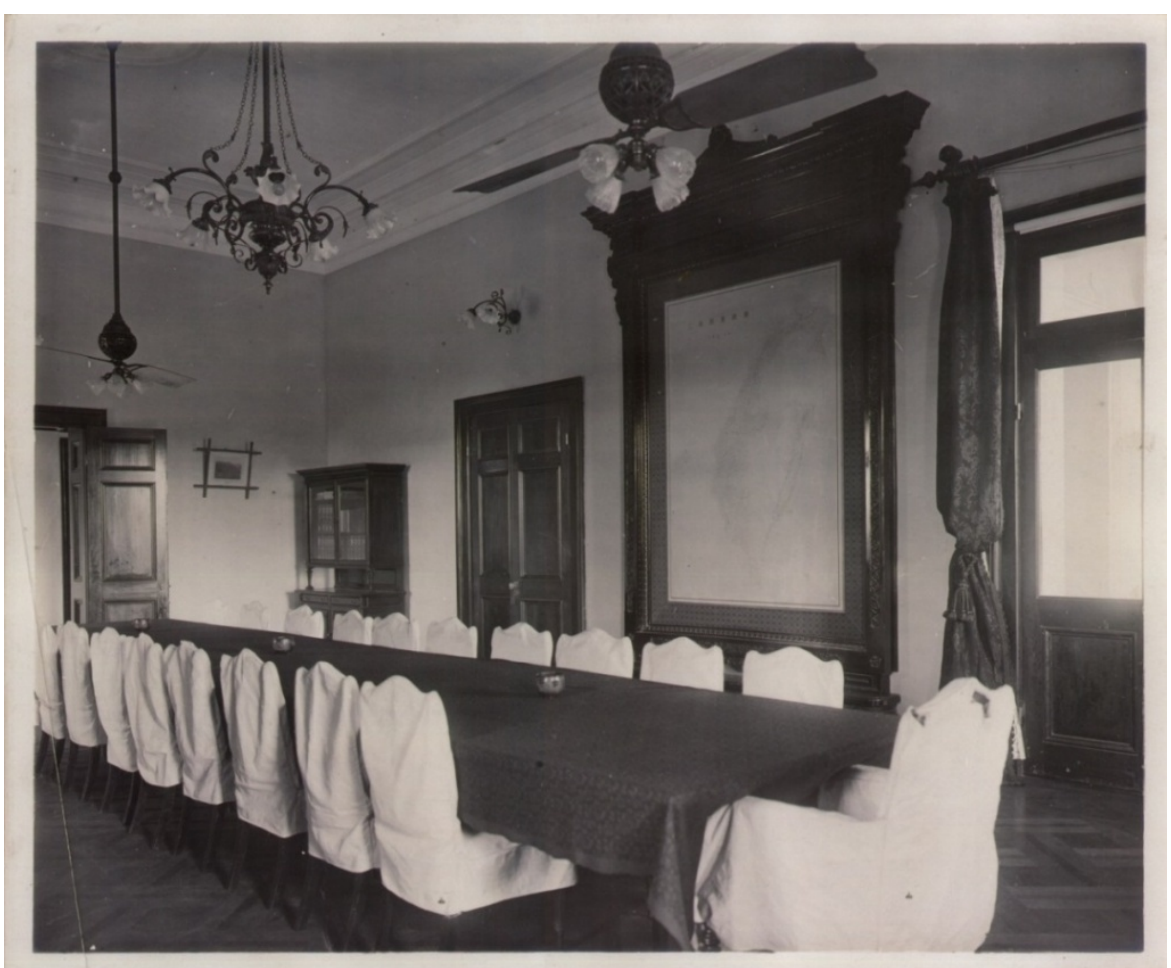

Figure 11. The meeting room at the ground floor of the Governor-General's residence. Image source: Huang Chun-Ming, The Story of the Office of the Governor-General: The Office and the Residence of the Taiwan Governor-General, Taipei, Rikui Culture, 2004, p. 51.

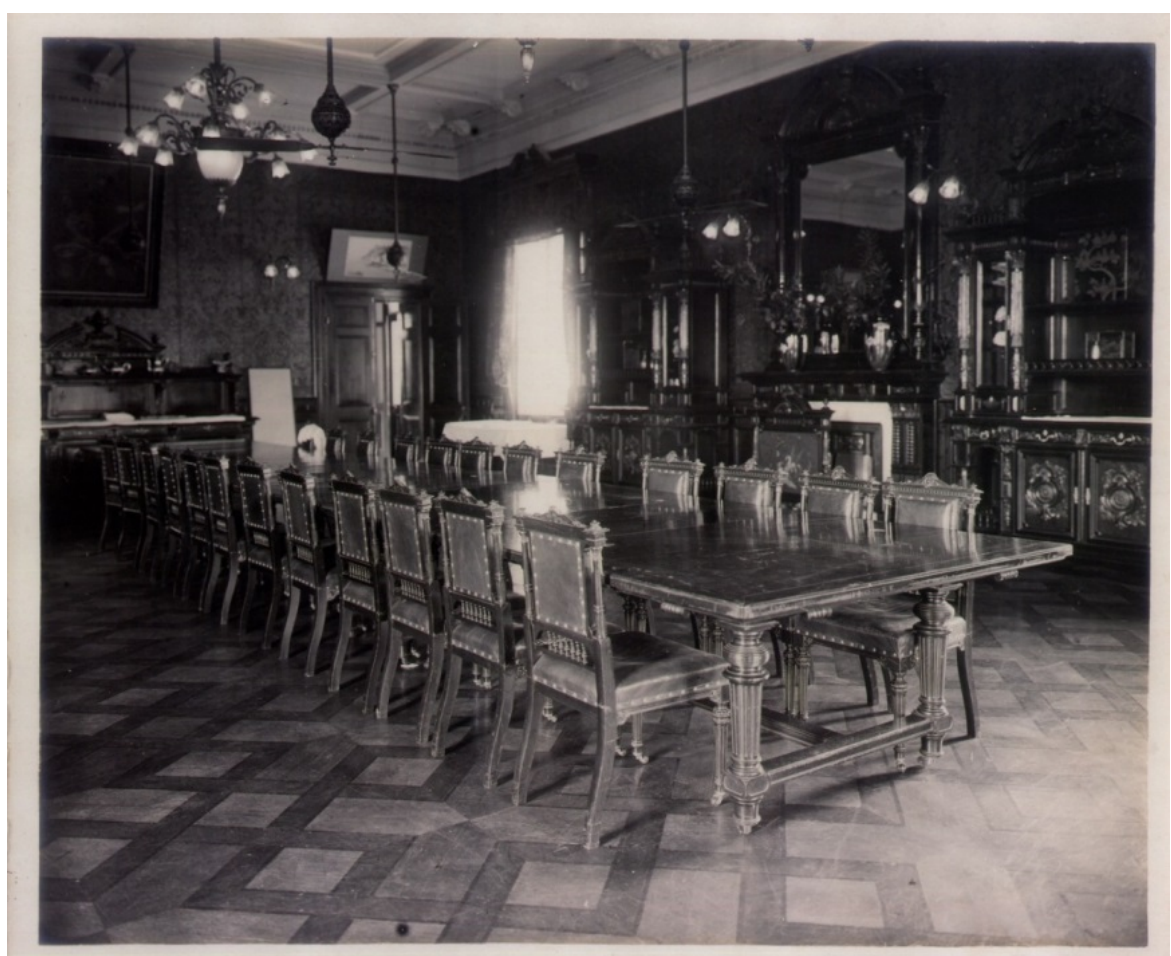

Figure 12. The large dining hall in the Governor-General's residence can be used for large banquets. Image source: Huang Chun-Ming, The Story of the Office of the Governor-General: The Office and the Residence of the Taiwan Governor-General, Taipei, Rikui Culture, 2004, p. 53. 


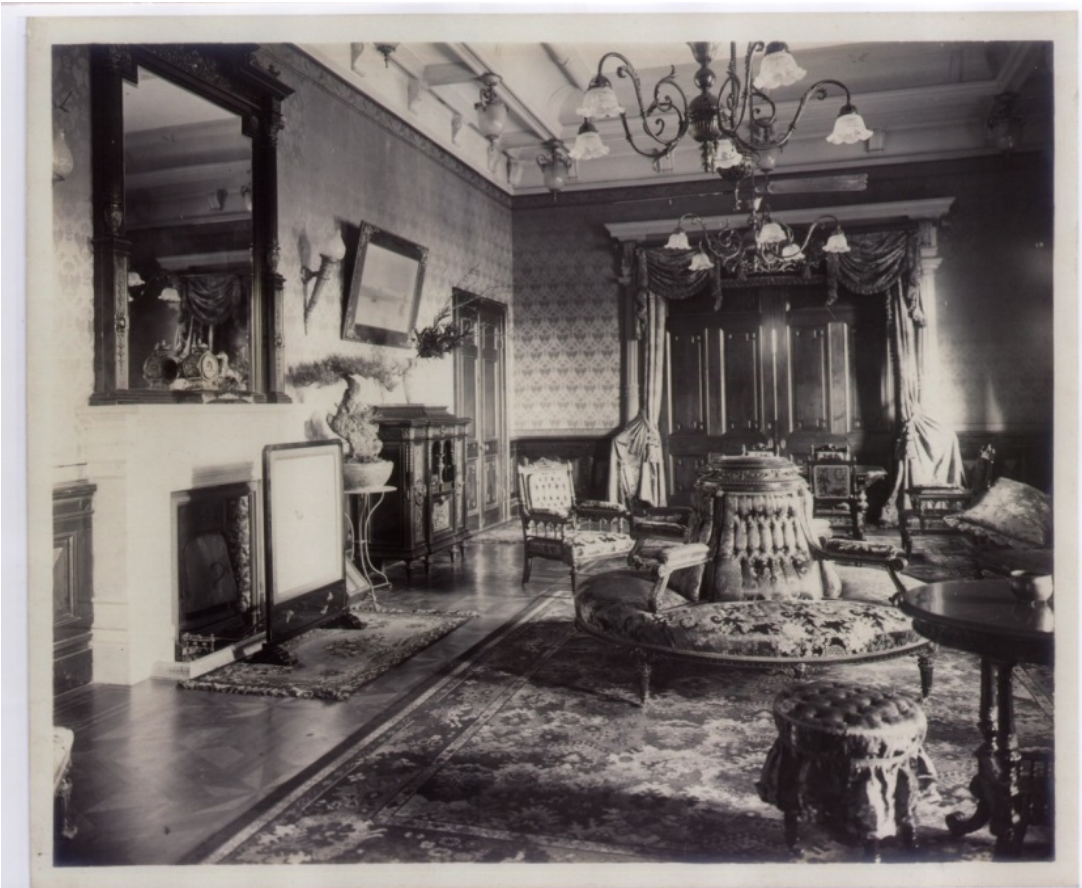

Figure 13. The reception room at the ground floor of Governor-General's residence is the main social space to receive visitors, where can directly access to the large dining hall. Image source: Huang Chun-Ming, The Story of the Office of the Governor-General: The Office and the Residence of the Taiwan Governor-General, Taipei, Rikui Culture, 2004, p. 51 .

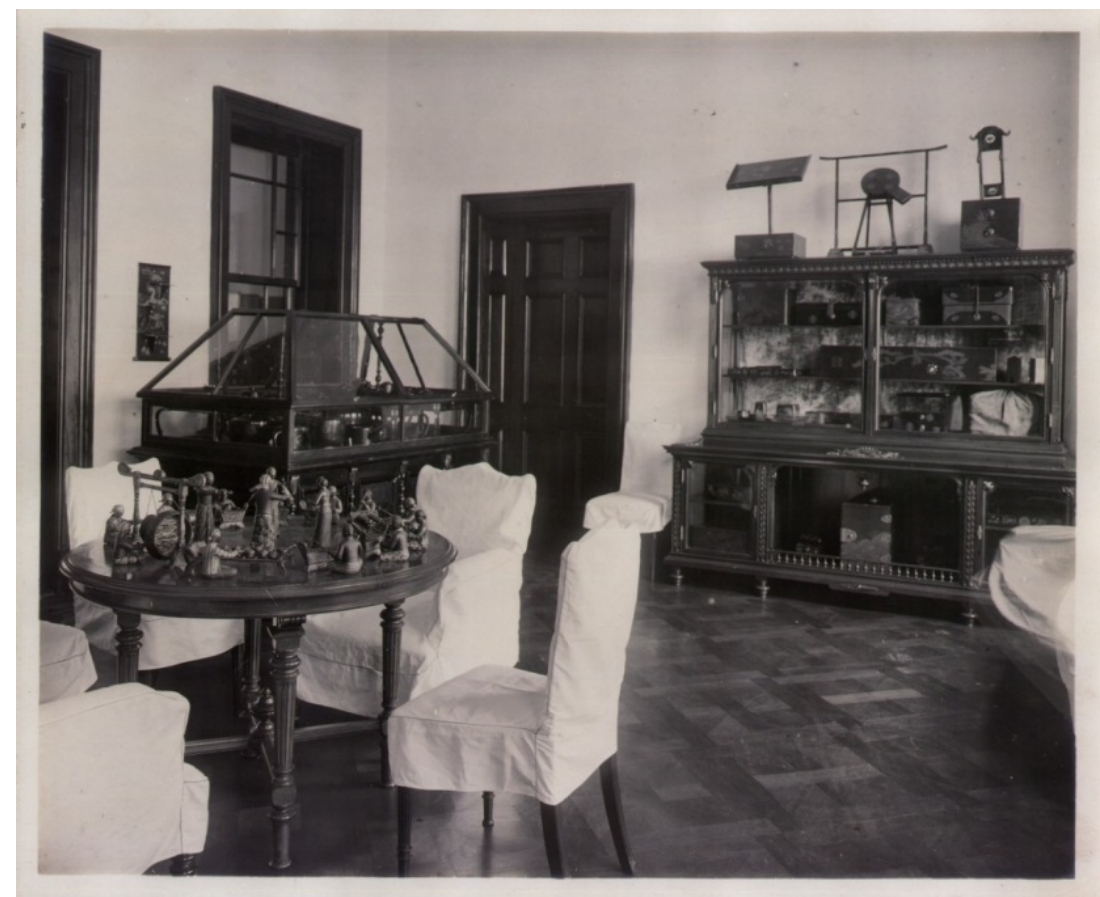

Figure 14. In the east side of the Comfort Room, on the 2nd floor of Governor-General's residence, you can see a collection cabinet to collect antiquities and artworks. This space is a collection appreciation room often seen in high society mansion, used for enthusiasts or guests to appreciate and enjoy, strongly showing occupants' class and taste. Image source: Huang Chun-Ming, The Story of the Office of the Governor-General: The Office and the Residence of the Taiwan Governor-General, Taipei, Rikui Culture, 2004, p. 56. 


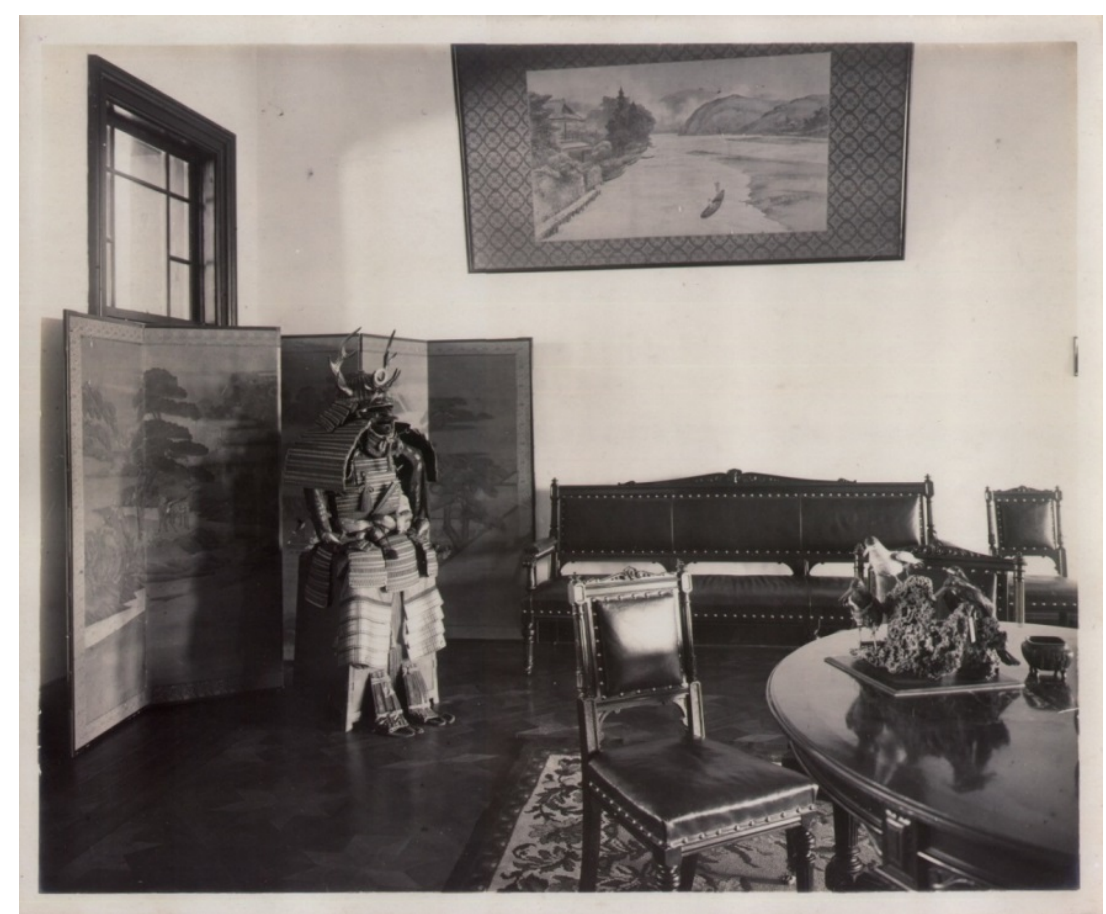

Figure 15. The southwestern corner of Hiroshima (hall) at the 2nd floor of Governor-General's residence; Hiroshima (hall) is carpeted, and placed with sofas, as well as displayed by pottery horses, screens, hanging scrolls, and ink paintings, etc., appearing to the parlor or living room purposes. Image source: Huang Chun-Ming, The Story of the Office of the Governor-General: The Office and the Residence of the Taiwan Governor-General, Taipei, Rikui Culture, 2004, p. 54.

Gardens. The garden is also an extremely important part of the Taiwan Governor-General's Residence in Taipei. The front garden is basically a necessary buffer for architecture and the city, while the backyard is special. Its beauty can make the owner act as a show-off place for the big banquet guests, and on the other hand, play a retreat space when privately enjoying it. From the old photo view, the original garden of Taiwan Governor-General's Residence in Taipei has a vast pond, and now it is full of grass and trees. There was also an oriental-style bridge on the water. The time for the garden to change is still to be verified, but after the Western-style architectural main body, there was an oriental style garden that is interesting (Fu, 2009, pp. 184-191).

Park in Taipei Town at that time is today's 228 Peace Memorial Park. This part of establishing a park is also an initiative, just because there was private cemetery only, without the public park for public use in Qing Dynasty. The park concept comes from Europe in the 19th century, wanting to have a pastoral life in the city, and for the middle-class recreational purposes. In addition, there were telephones, electric heaters, and a variety of new equipment at that time (Huang, 2004, pp. 58-59).

In the peripheral garden design of Taiwan Governor-General's Residence (Fig. 16), there were a pond, and fountain lighting at night (Fig. 17), as well as an elegant Japanese garden made by rockery and pond. According to "Taipei Street Serial View" (Fig. 8), published on October 1911 (the 44th year of Meiji), you can find before reconstruction of official residence, there is a Western-style garden at the porch entrance; and in "The figure of Park in Taipei Town" (Fig. 18) as early as in 1906 (the 39th year of Meiji), some parts have been sketched out. But from the records made by Ishikawa Kentaro, an engineer of Civil Engineering Division, 
because of no extra cost to plant tree, first transported nearly thousand strains of acacia from the site of Amy Garrison Hospital on the upstream of Beitou hot spring area. Moreover, transplanted two large banyans beside South Vegetable Garden (Fig. 19) near Guting Zhuang Villa, the favorite by Governor-General Kodama were respectively transplanted into the official residence's garden. However, due to lack of transportation costs, they seconded the inmates in the prison to carry the trees; for the wires obstruction in the way, he ordered the Information Delivery Bureau to temporarily cut the wires to facilitate access and to move the banyans into the garden that the Govern-General's majesty is visible.

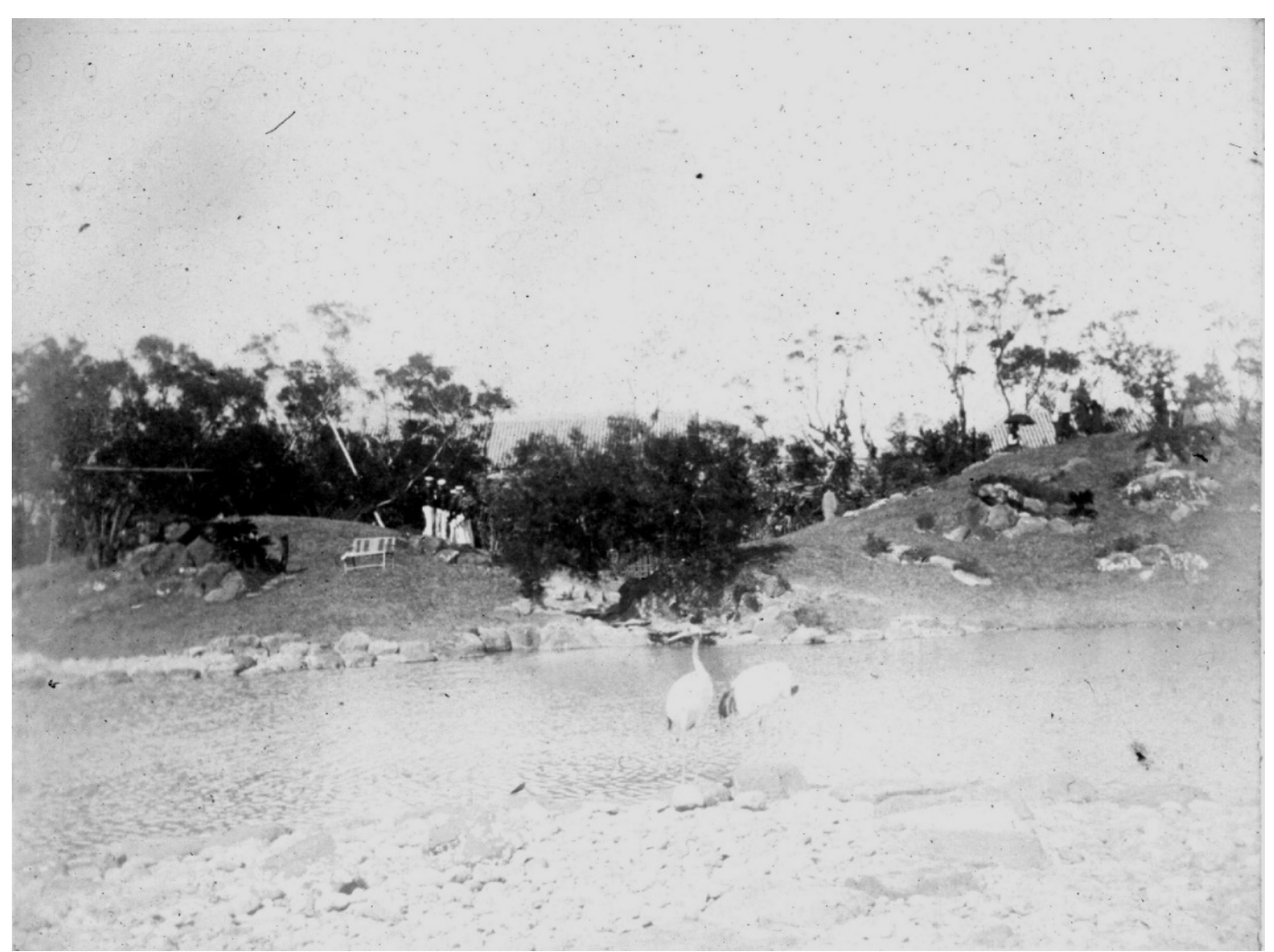

Figure 16. The Japanese garden arranged with rockery and pond at the rear side of the Governor-General's residence. Image source: Huang Chun-Ming, The Story of the Office of the Governor-General: The Office and the Residence of the Taiwan Governor-General, Taipei, Rikui Culture, 2004, p. 57. 


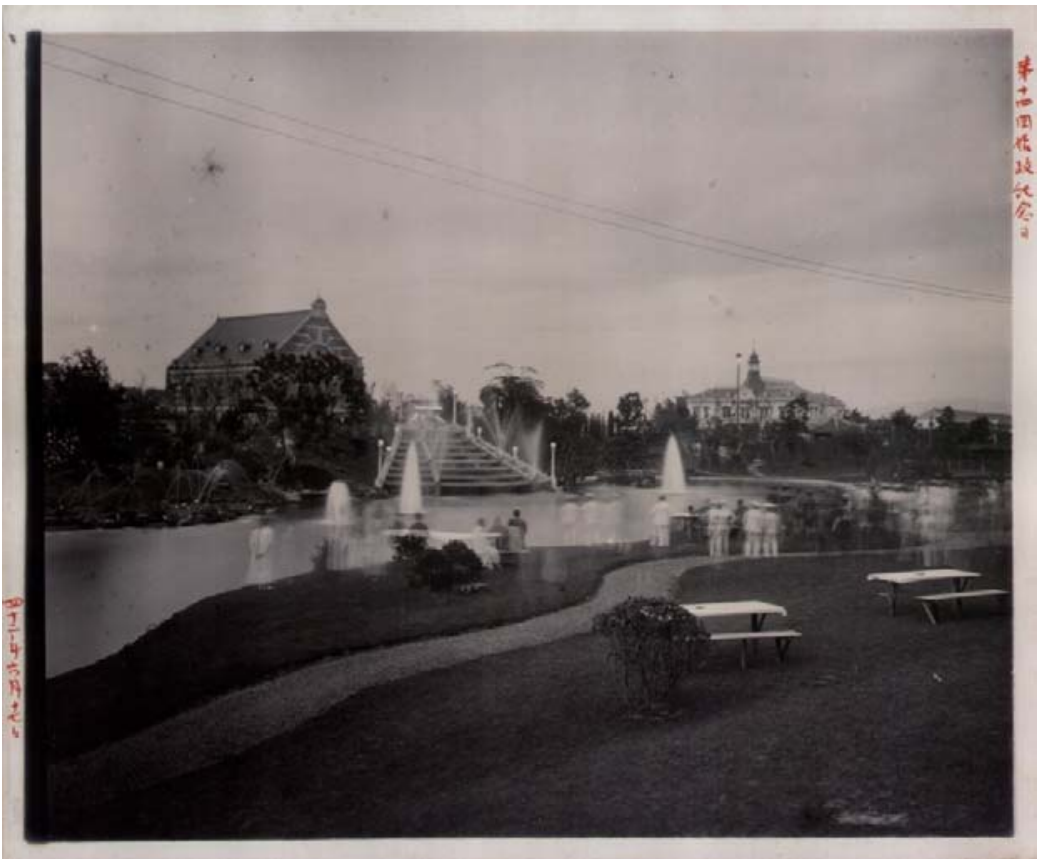

Figure 17. Early fountain landscaping garden, also provided with lighting at night to illuminate waterscape. Image source: Huang Chun-Ming, The Story of the Office of the Governor-General: The Office and the Residence of the Taiwan Governor-General, Taipei, Rikui Culture, 2004, p. 57.

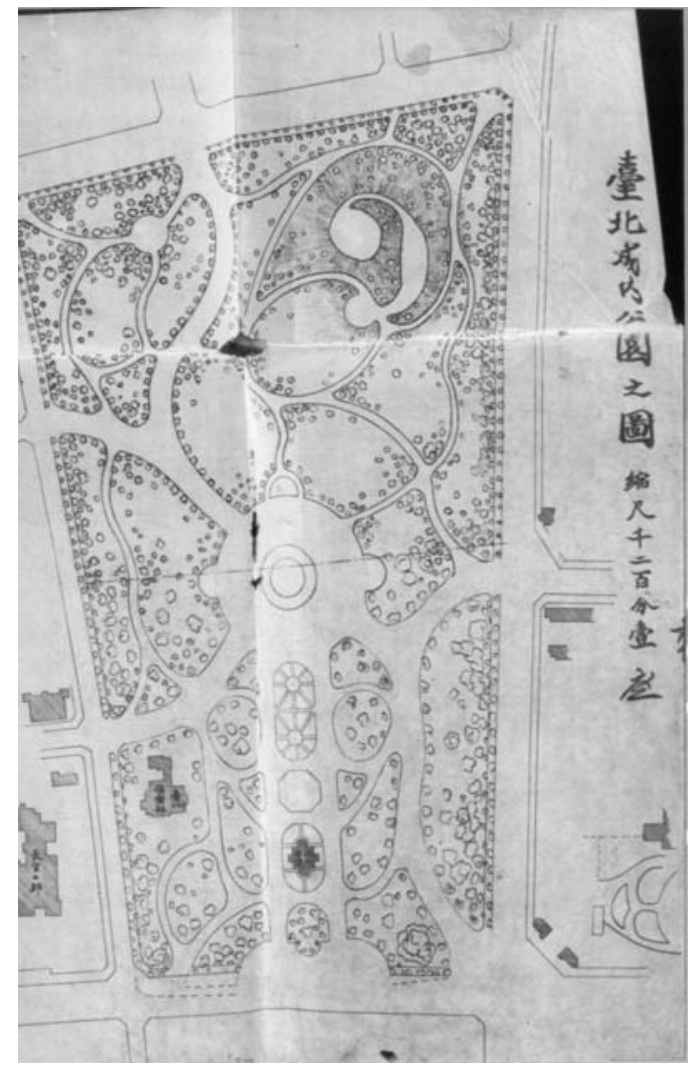

Figure 18. 1906 "The figure of Park in Taipei Town"; the park in Taipei town is the New Park at the time. Image source: Huang Chun-Ming, The Story of the Office of the Governor-General: The Office and the Residence of the Taiwan Governor-General, Taipei, Rikui Culture, 2004, p. 59. 


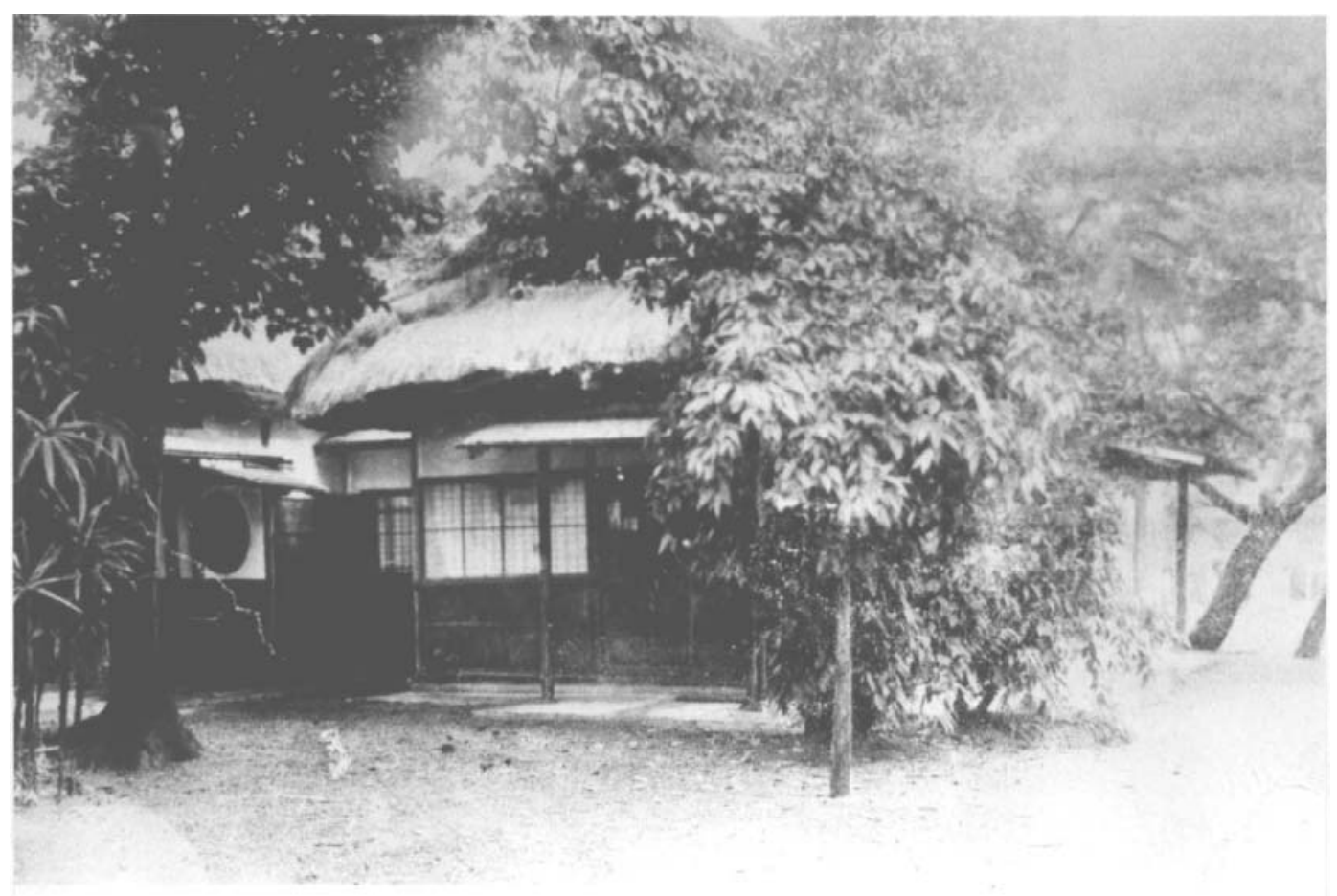

Figure 19. In the center of detached residence, "South Vegetable Garden" built by Governor-General Kodama Gentaro; there is a wooden Japanese bungalow with grass thatch roof. Image source: Huang Chun-Ming, The Story of the Office of the Governor-General: The Office and the Residence of the Taiwan Governor-General, Taipei, Rikui Culture, 2004, p. 60 .

\section{Architectural Decoration and Symbol}

Renaissance style and decoration. Taiwan Governor-General's Residence designed by Renaissance style $^{3}$, using bricks and stones to construct into a two-layer building with iron beams in which concrete was filled, was completed in 1901. Slate laying roof, interior wooden parquet floor of both floors, and British tiles laid in large Hiroshima (hall) center in the ground floor and outer gallery walkway. Outside the ancillary buildings, in addition to stone guard office (now known as the guard room), there were wooden charioteer Martin quarter and stables. In front and back of the main building of the Governor-General's residence, there was Western-style garden with fountain, and a Japanese-style garden with rockery and pond, very elegant. There was stained glass in the interior space. Stained glass is mainly the art in middle century in West, rarely on the interior. In addition, there is a plaster sculpture of deer head, a symbol of ruling the colony, Taiwan. Besides, on the second-floor space the Governor-General can watch the parade, with political implications.

\footnotetext{
3 The Renaissance architecture originated in Italy in the 15th century, because it was introduced to France, Britain, and other countries with the origins of the French aristocracy and the Holy Roman Empire. At that time, when the French were introduced to the Gothic tradition, the Renaissance style only affected the performance of the court and noble buildings. In the UK, the official introduction of the Elizabethan dynasty in the 17th century was the trend. In the 19th century, France, the United Kingdom, and other countries revival of a historical style. The Renaissance architecture has sprung up in many historical styles, replacing the neoclassicism prevailing in the 18th century. It has once again been valued and used in palace buildings. Historically, it is called the new Renaissance style. The prevalence of neo-Renaissance architecture in Europe has also affected many international students from other countries to Europe. On the other hand, European professors from Europe to other countries have also brought the architectural style with Western historical styles to the local area and influenced the local architectural style. Among them, after the Meiji Restoration, Japan was influenced by historical style buildings introduced from the West. In the royal family's or the Chinese luxurious residence, you can see the historical style of the neo-Renaissance style or the later neo-Baroque style.
} 
Baroque style after reconstruction. Because of long-term termite problem of a decade after completion, and not taking into account the function to receive the royal family to Taiwan at the initial design, the space of Governor-General's residence was always not inadequate whenever royal members visited to Taiwan, and therefore it was funded for reconstruction in 1911. The reconstruction was completed in 1913. The reconstruction designer, Moriyama Matsunosuke, made the space of reconstructed Governor-General's residence larger, and entire building was changed from Renaissance style into Baroque style, even more magnificent.

The reconstructed Governor-General's residence used advanced mixed construction techniques, introducing steel, and reinforced concrete to combine with the original brick structure. The steel reinforced replacing the wooden beams can prevent from termites and fire, with a considerable practical design. There were great changes in the spatial pattern, except retaining the original reception space of entrance, the original central aisle at left and right sides of the building was no longer the main moving line, but a few arches of each space were connected for passage (Huang, 2004, pp. 49-55). Baroque architectural features of Governor-General's residence ${ }^{4}$ is reflected in the complex decorative columns and gables. Its roof was changed into steep tall Mansard roof (Fig. 20), and four faces outside of the building were also changed to double-column style (Fig. 21) from single-column style. The interior is gorgeous plaster sculpture, and there were crystal lamp means in the lobby, dining hall and staircases. In addition, there were advanced beech parquet flooring, British imported Victorian tiles and fireplace, thick plush carpets, window with iron grating, door curtain, and high-quality furniture, having demonstrated honorable status of those people whose activities were in the official residence (Huang, 2004, pp. 64-70).

\footnotetext{
${ }^{4}$ In the 19th century in Europe, the neo-Renaissance and the neo-Baroque style replaced the neo-classical architectural style, and the trend influenced Japan and became the taste of the Japanese upper class. The designer, Matsuo Moriyama, understands the psychology of the Japanese royal family and designs the Taiwanese governor's official residence to be a powerful Baroque building to receive the visiting Japanese royal family.
} 

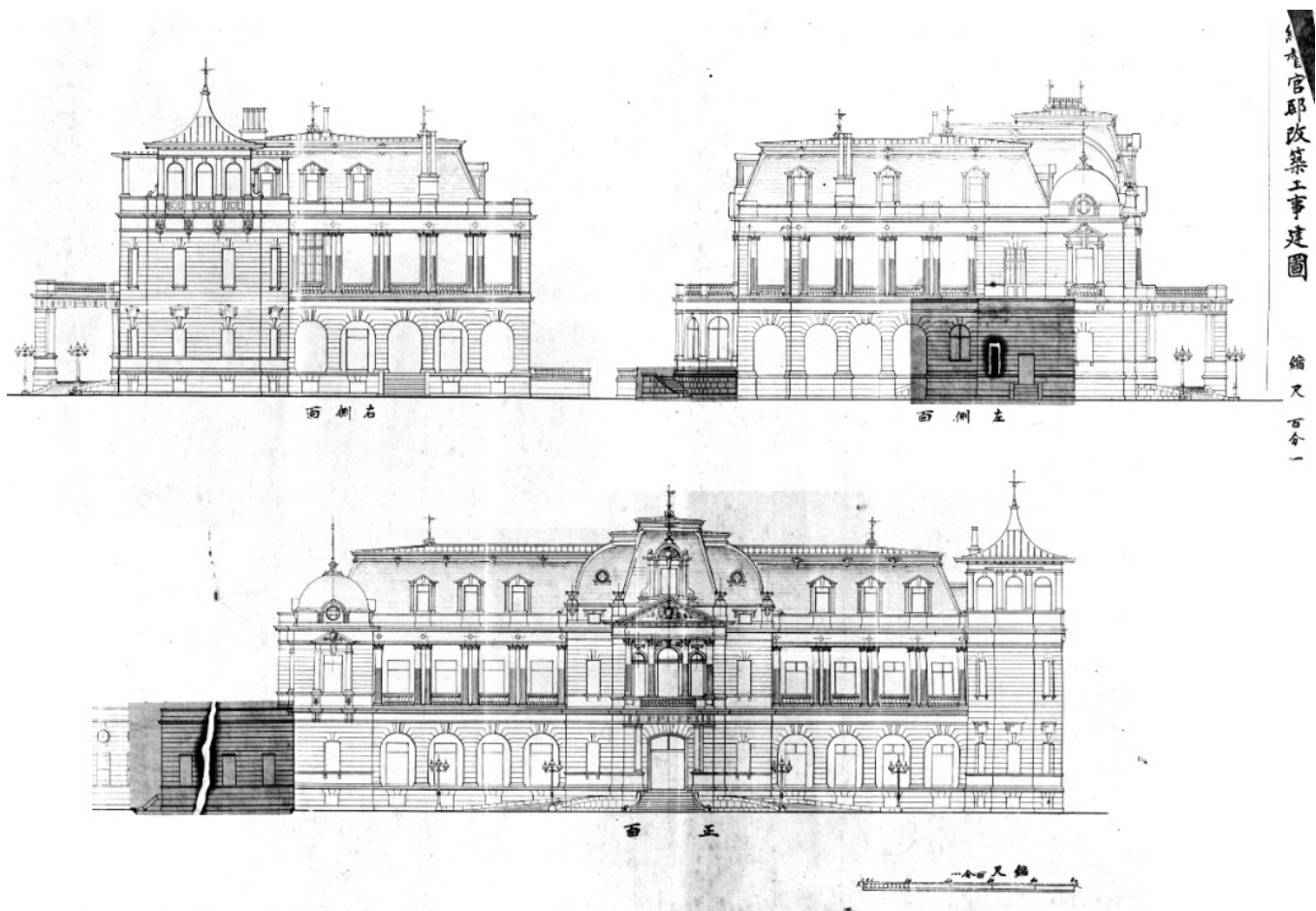

A

Figure 20. The east, west, and south elevations of 1911 reconstructed Governor-General's residence. Image source: Huang Chun-Ming, The Story of the Office of the Governor-General: The Office and the Residence of the Taiwan Governor-General, Taipei, Rikui Culture, 2004, p. 64.

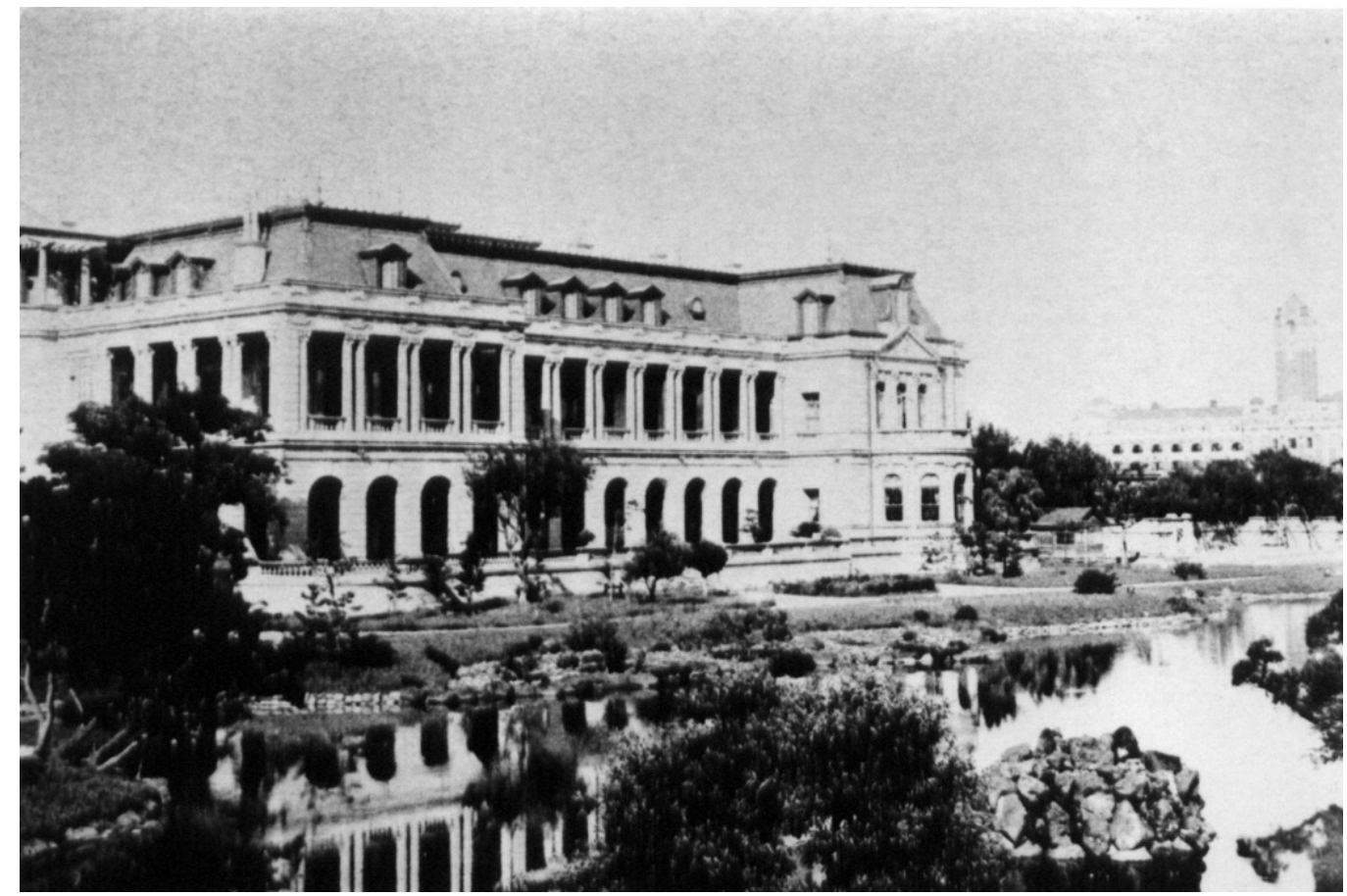

Figure 21. After the Governor-General's residence was reconstructed, the architectural style was even changed from the Renaissance style into Baroque style. Such as the uprights of balcony were changed into double-column from single-column; in addition to the original stable, but also a lot of luxurious visual effect were added too. Image source: Huang Chun-Ming, The Story of the Office of the Governor-General: The Office and the Residence of the Taiwan Governor-General, Taipei, Rikui Culture, 2004, p. 62. 


\section{Japanese and Western Style}

\section{Japanese Style}

After the renovation, the first room in the southeast corner was a Japanese-style living room with tatami. During the Meiji period, the phenomenon of the coexistence of Japanese and foreign styles in upper class's mansions was very popular. A Japanese room was set in a western house. This living room offers the only social, and living space of the Baroque official residence (Huang, 2004, pp. 70-71). In addition to living in the Governor-General's residence, the Governor-General has a Japanese-style house called the South Garden. In the Governor-General's residence, it is mainly Western etiquette, but in the South Garden, it is a Japanese style where the Governor-General, Kodama returns to the traditional Japanese life, planting vegetables, reading, and playing chess with the poet, returning to the traditional life of Japan.

\section{French Style}

Mansard roof, French garden, and reception room (Fig. 13), like the French palace style in the 19th century. The photo shows the carpet, the fireplace, the mirror, and the French court chair. The only thing that still has a Japanese style is pine potted.

\section{English Tiles}

The 17 rooms each have different tiles, reflecting the pattern of the tiles according to the importance of the room, so the tiles of the fireplace in each room are different.

\section{The Design of the Plan Is an Extension of the Japanese Style and Western Style Mansion, Imitating Versailles}

Japanese and Western mixed style at the time: There is a reception room and a pool room, combined with the traditional Japanese Hirosima (hall). In the Japanese tradition, Hiroshima received guests, but at the time there was a larger reception room to accommodate guests. Japanese traditional houses can be divided into "Ma", "Gyo", and "Kusa". The "Qyo" represents daily life, and "Kusa" represents leisure, such as Japanese teahouse culture. "Ma" represents meeting or reading, so the pool is converted into Japanese teahouse space.

Japan's famous Japanese and Western building, such as Hisaya Iwasaki's Residence (Fig. 23). Regarding the Japanese and Western buildings set in the residence in the Meiji's period, it is easier to think about the difference between the daily (simple) of Japanese style building and the reception (gorgeous) of Western-style building. To be correct, it should be a larger hospitality space before the hospitality part of the Japanese and Western (Hirosima). For the noble gentlemen during Meiji period, the Western room is actually a "Shoin-zukuri" (Japanese residential architecture) of the new era, and new large Hirosima. Although this kind of Western-style building began to sprout from Jyuudou Saigou, it can be said that it was only after the construction of Conder's orthodox Western-style building was established. 


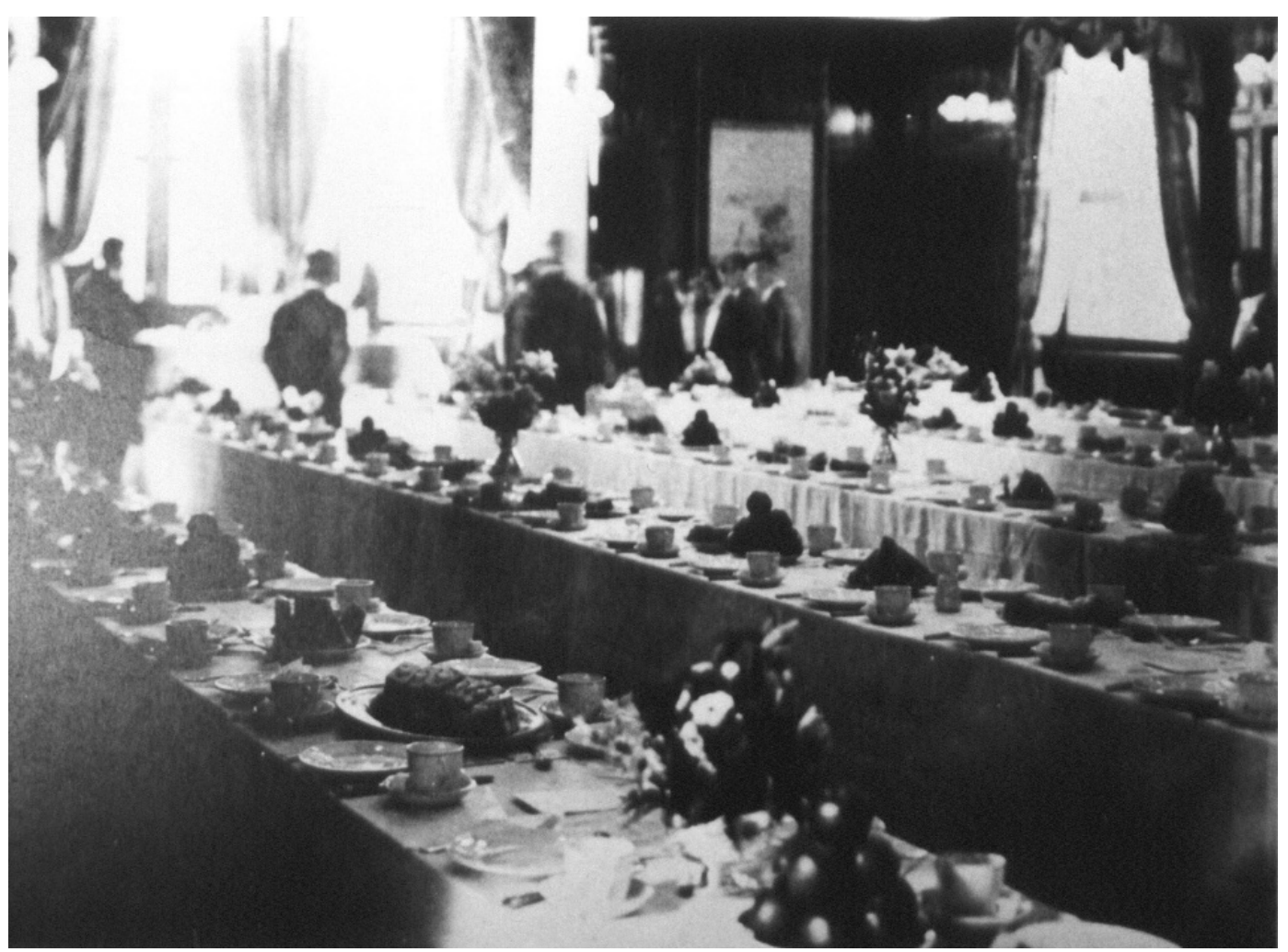

Figure 22. The Japan crown prince entertained officials and the public in the Large Dining Hall on the ground floor. Image source: Huang Chun-Ming, The Story of the Office of the Governor-General: The Office and the Residence of the Taiwan Governor-General, Taipei, Rikui Culture, 2004, p. 78. 


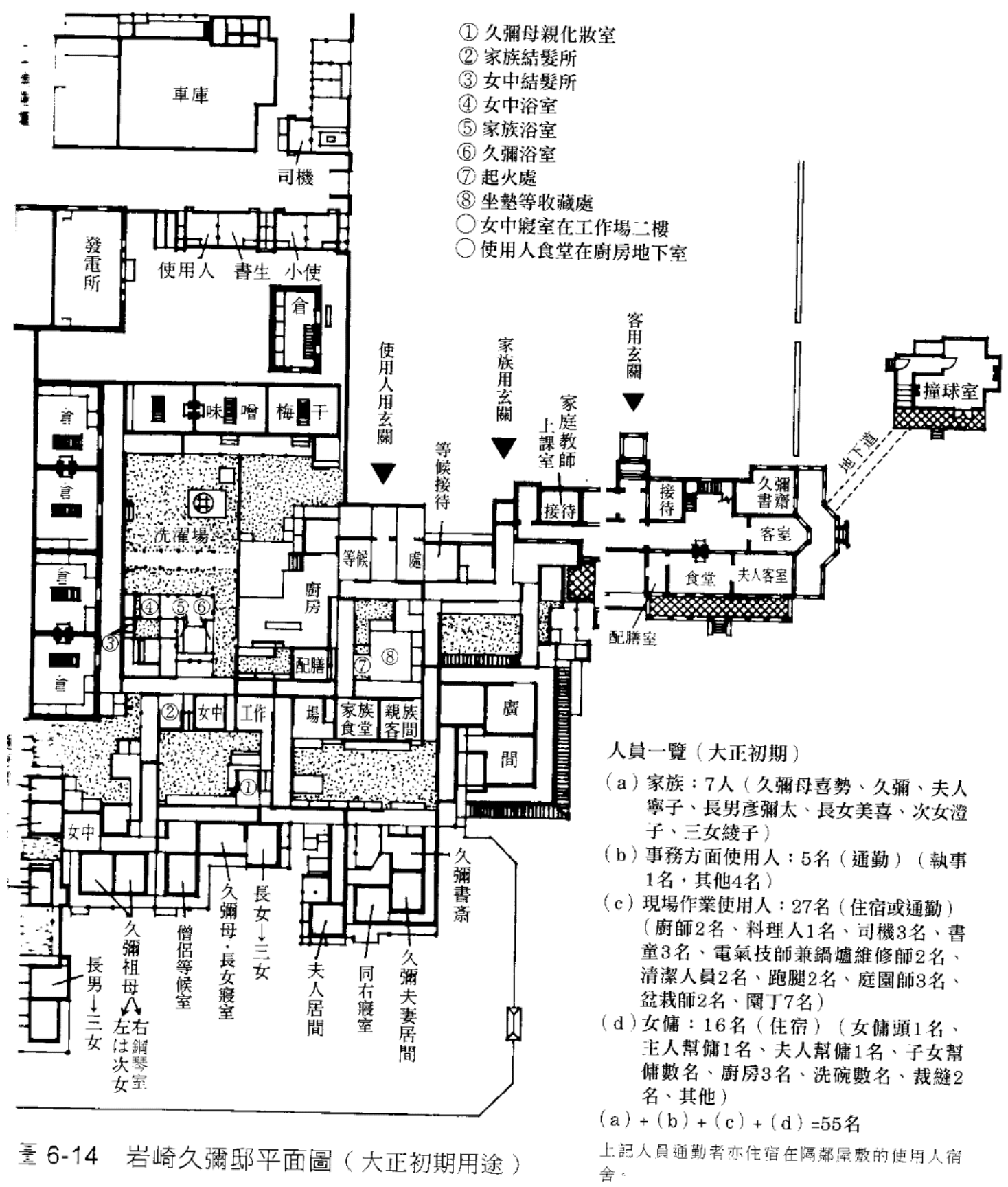

Figure 23. Hisaya Iwasaki's Residence floor plan.

The Japanese-style Hirosima (hall) and Western-style pool room are gradually staggered in the form of geese flying. If you look at the pool room from Hirosima (hall), you will think that it is a small place in a very deep distance. It is obvious that there is a duplication with the room configuration of Japanese traditional residence. In the traditional configuration of the Japanese style residence, the configuration of "Ma", "Gyo", and "Kusa" is highly valued. The large-scale Hirosima (hall) belongs to the "Ma", which is Shoin-zukuri; other entertainment venues are classified as "Kusa", such as tearooms, which are differentiated according to the 
nature of use. The relationship between Ma-Shoin Zukuri, Gyo-Sukiya Zukuri, and Kusa-Tea Room can be felt in the configuration of Hirosima (hall) and Western-style pool room by Iwasaki Hisaya. Hirosima (hall) is a form of Shoin-Zukuri, and pool room is a Western-style tea with a mountain-house style. The use method of Conder's Western-style building built by Iwasaki Hisaya became a model for the future mansion and lasted for a long time (Fujimori, translated by Huang, 2008, pp. 146-153).

Taipei Guest House's floor plan was designed to mimic the Palace of Versailles, but the transition and extension of the Japanese-style and Western-style buildings can be seen, so Taipei Guest House also has Japanese-style room.

\section{French Front Garden and Japanese Garden}

Japan used to receive guests in the garden but there was no Japanese garden designer to study in Europe at that time. Therefore, even if the Japanese-style house in Japan was still equipped with a Japanese garden, Taiwan Governor-General's Residence has the same principle. There is also a special feature: Taiwan Governor-General's Residence is an office receptionist and enjoys painting. The balcony was also a colonial building at the time for overlooking the garden.

Horizontal friezes reaction at the time of the policy: industrial Japan, agricultural Taiwan. Western fruit friezes turned into different fruits of Taiwan, such as: wax apples, and guava.

\section{Art Activities at Taiwan Governor-General’s Residence}

\section{Various Activities to Entertain the People and Officials of Taiwan}

The objects to entertain included religious figures, scholars, gentry, and local officials, with the effect to draw people's heart. For example, a tea party to receive people and officials in the residence held on July 10, 1915 (the 4th year of Taisho). On October 24, 1921, Governor-General Den Kenjiro invited his Taiwan friends to hold poetry meeting in the official residence. Tables and chairs were arranged and pen and ink were placed within the north balcony facing the garden. Everyone enjoyed the garden for creating poetry. To the Memorial Day with special meaning to Japan, large-scale celebrations will be held in official residence too, such as the congratulation meeting held in 1925 (the 14th year of Taisho) for executing political power three decades in Taiwan. For the Memorial Day of executing political power in other years, the official residence is often used to hold tea party or garden party. From the above social events, you can see when there are a large number of people, lunch or dinner banquet and other activities primarily use the north space of garden and terrace; for smaller number of people, the large restaurant on the ground floor will be used. The garden at north side has vast area with beautiful scenic views, playing a very important role on the official residence in the arts and social activities. In addition, during the New Year, the square takes a Japanese stage which was built in the square for celebration (Fig. 24). 


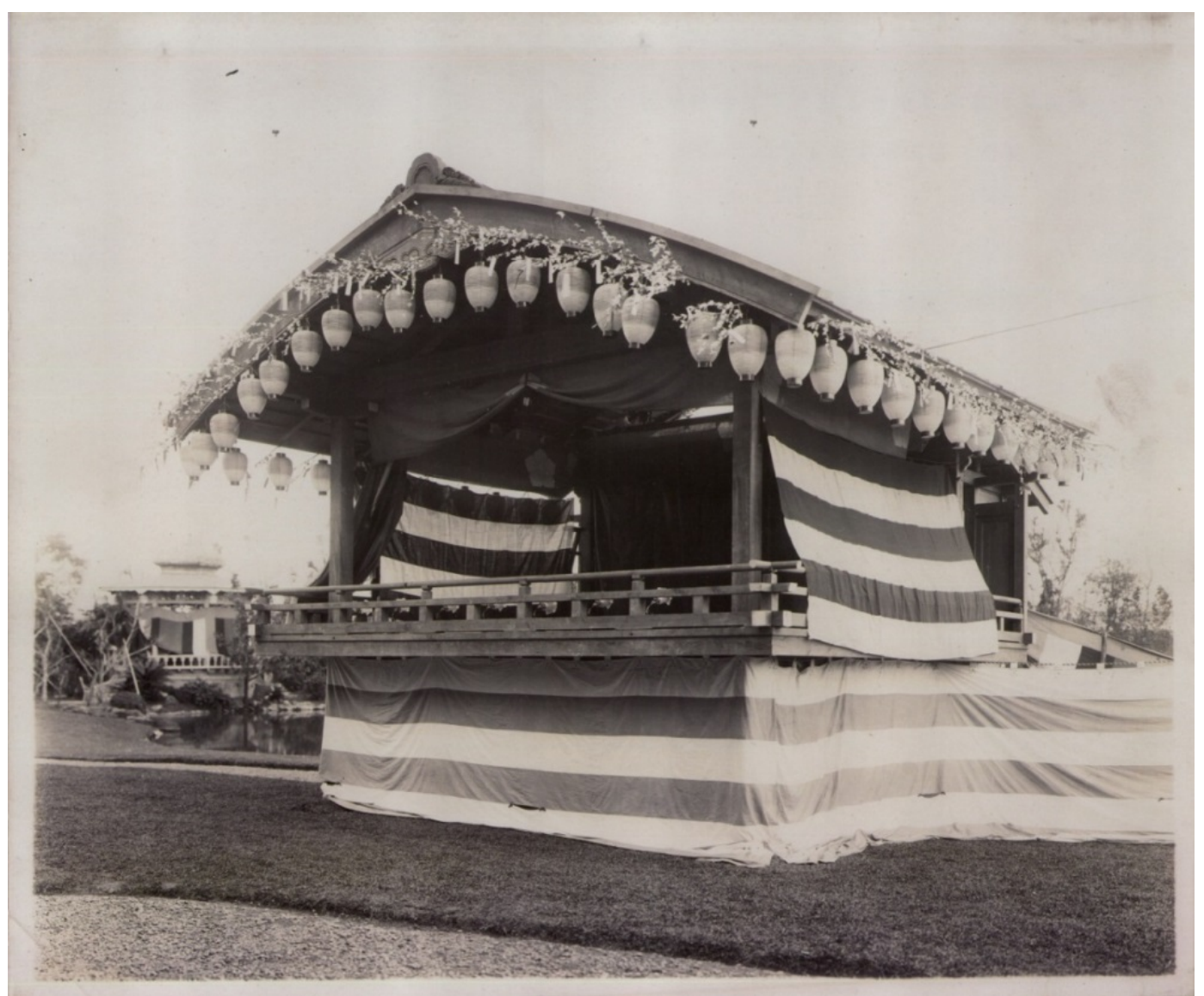

Figure 24. The temporary Japanese play stage set up in the north balcony for festival. Image source: Huang Chun-Ming, The Story of the Office of the Governor-General: The Office and the Residence of the Taiwan Governor-General, Taipei, Rikui Culture, 2004, p. 76.

\section{Parade Events to Welcome Royal Family}

Taiwan Governor-General on behalf of Mikado is normally the supreme ruler of the colony, but when the Japanese royal family, and princes of each palace patrol Taiwan, the Governor-General must temporarily move out of official residence, letting the Japanese royal family and entourages into the official residence temporarily. In order to receive Japanese crown prince's visit to Taiwan, newly construct tennis court, dining room, and billiards room, replace lace curtain, lay pile carpet and linseed oil blanket, replace electrical equipment, and water heater, increase indoor and garden lighting, in addition to building an imperial supplies sterilization office, as well as adding a lot of ornate furniture. The Government-General of Taiwan also welcomed the crown prince with the special arrangements lantern procession. The parade was consisted of Taiwan's various groups from the government office, and school students, about 25 thousand people; the crown prince ascended onto the third-floor balcony of the official residence to accept the welcome ceremony by officials and the public. The condescending second and third floor balconies become the best place for crown prince's tour. In addition, the crown prince with entourages appreciated the orchestras of Qing Dynasty in Hiroshima (hall) at east side of the 2nd floor. The players are Dadaocheng gentries Chen Chao-Chun, and Chen Tien-Lai et al. On the next day, crown price in the garden summoned male and female representatives of Taiwan aborigines. The princess received Taiwan aboriginal tribes (Fig. 25). It can be seen from the photo that the princess is wearing a 
parasol, wearing a dress, just like the Western-style lady in the French Impressionist, and the surrounding aborigines, wearing traditional clothes, in a strong contrast.

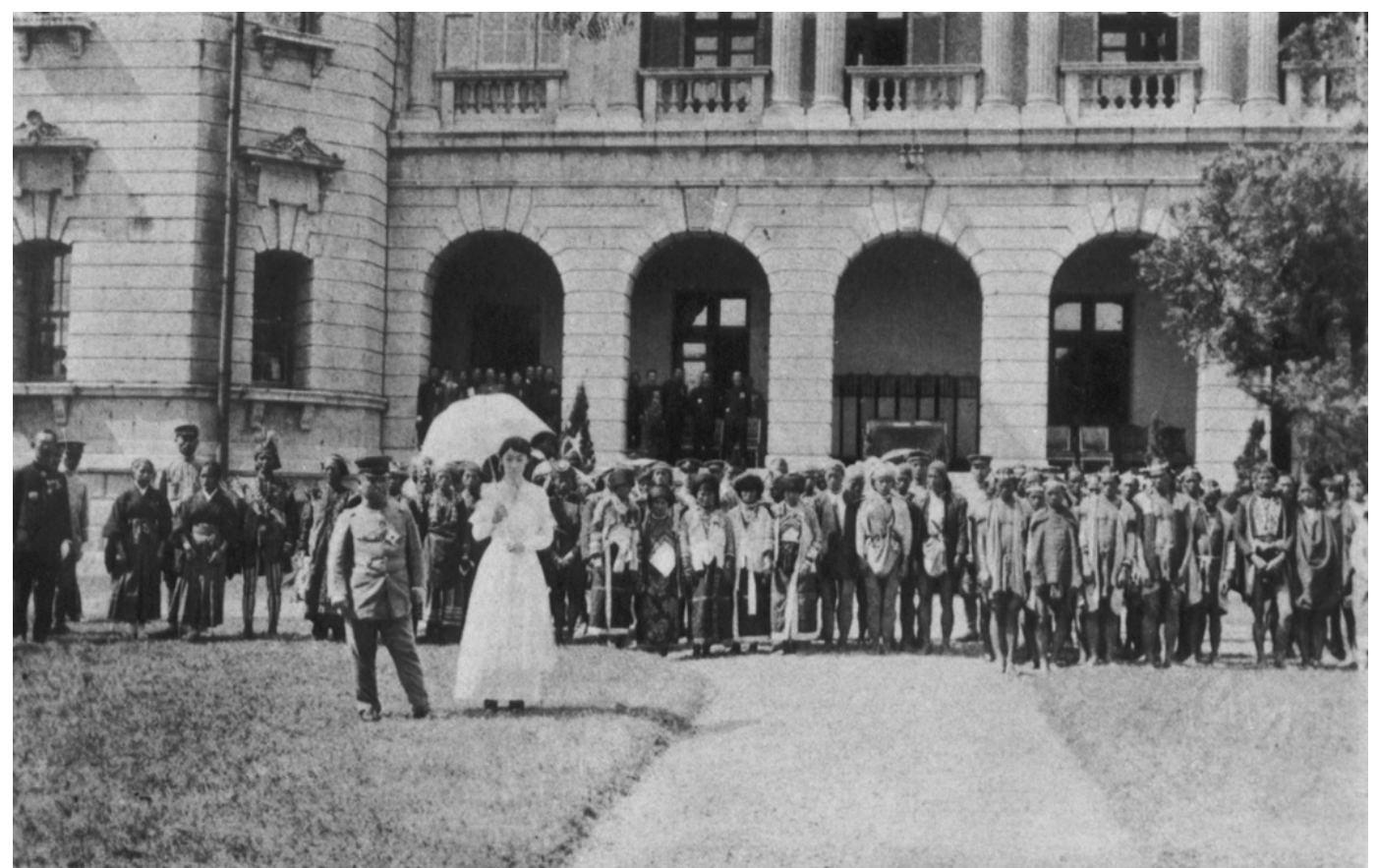

Figure 25. The north balcony and garden of the Governor-General's residence is the most frequently used place to entertain the large number of people. The picture shows Kitashirakawa Princess met with aborigines. Image source: Huang Chun-Ming, The Story of the Office of the Governor-General: The Office and the Residence of the Taiwan Governor-General, Taipei, Rikui Culture, 2004, p. 72.

Japan, during the reign in Taiwan, on the one hand carried out military control; on the other hand adopted the policy of appeasement, entertaining religious figures, scholars, gentry, and local officials to draw people; for instance, on July 10, 1915, a tea party was held in the official residence, receiving officials and the public.

On October 30,1916, the chief of Civil Affairs held a luncheon to entertain people of all religions in Taipei. On October 24, 1921, Den Kenjiro, the eighth Governor-General used the interior space and Japanese garden of Governor-General's residence to hold poem meeting, inviting friends of whole Taiwan to participate in. In addition, if on festival day or Memorial Day, a stage also will be erected in the Governor-General's residence to hold garden party or dinner party, and other activities. When the member of Japanese royal family tours Taiwan, Governor-General's residence also became the temporary place to live for royal family member handling activities in Taiwan. This section provides a glimpse of the relationship between the colonists and the various ethnic groups in Taiwan. This building has the meaning of class separation and political function (Huang, 2004, pp. 71-77).

\section{Conclusion: The Impact of Taipei Guest House}

According to Fu Chao-Ching's article "Taiwaneseness in Japanese Period Architecture in Taiwan", through the influence of the Baroque architecture during the Japanese rule, the city hall and the station have a Western historical style, and also affect Taiwan's prosperous streets, so that there are Baroque old streets in every area. Local artisans used local elements of Taiwan, such as surnames, Taiwan's patterns. Only the facade is Baroque, and the interior is still the traditional architectural pattern of Taiwan (Fu, 2007, pp. 176-189). At 
this time, the main body of Taiwanese art is localized in the station or Baroque street decoration, and the Baroque pattern is transformed into Taiwan's fruit pattern (Fig. 26). For example: Taichung Railway Station shows the Western facade decoration friezes mainly with white horizontal friezes is mainly used, and the horizontal dividing line of the façade and the window frame are surrounded by white friezes. The Western pattern ornament is transformed into Taiwan's specialty fruits, wax apple, pomegranate, banana, pineapple, etc., full of fun, reflecting out of Taiwan's local characteristics (Liu, n.d.).

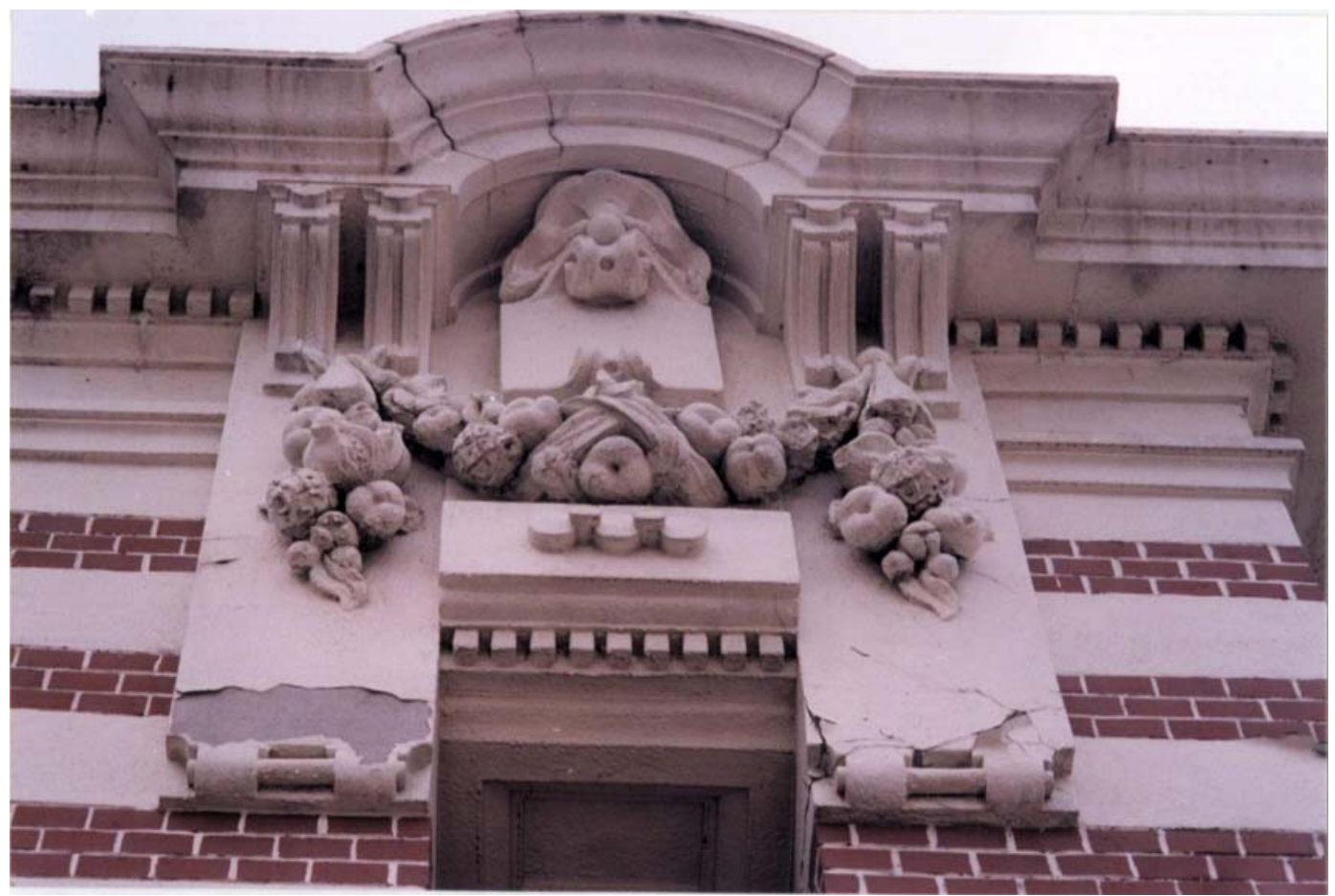

Figure 26. Decoration of Taichung Railway Station. Image source: http://www.yjes.tc.edu.tw/tcts/a13.htm.

\section{References}

Barlow, T. E. (Ed.). (1997). Formations of colonial modernity in East Asia. Durham \& London: Duke University Press.

Chen, J. M. (2001). Modernity and post-modernity. Beijing: People's Publishing House.

Chang, H.-M. (2013). The 7th office of the Taiwan governor-general archives symposiums. Nantou: Academia Historica, Taiwan Literature Hall.

Ching, T. S. (2006). Becoming “Japanese”: Colonial Taiwan and the politics of identity formation (1st ed.). (L.-H. Cheng, Trans.). Walls of Taipei: Rye Field Publishing Co., issued by Cite Publishing Ltd.

Fujimori, T. (2008). Modern Japanese architecture. (C.-M. Huang, Trans.). Taipei: Wunan.

Fu, C.-C. (2007). Taiwaneseness in Japanese period architecture in Taiwan. In Refracted modernity: Visual culture and identity in colonial Taiwan (pp. 169-191). Honolulu: University of Hawaii Press.

Fu, C.-C. (2009). Illustrated Taiwan architectural cultural heritage-in Japanese rule 1895-1945. Tainan: Taiwanese Architectural Culture.

Huang, C.-M. (1999). National monument “Taipei Guest House” study. Taipei: Ministry of Interior.

Huang, C.-M. (2004). The story of the office of the governor-general: The office and the residence of the Taiwan governor-general. Taipei: Rikui Culture.

Hualian County Cultural Affairs Bureau. (September 20, 2016). Retrieved from http://www.hccc.gov.tw/zh-tw/CulturalHeritage/Detail/28 (August 29, 2017)

Lin, M.-H. (2009). The exhibition at the ground floor of presidential place. "From the office of the governor-general to presidential palace": The story of the governor-general. Taipei: Academia Historica. 
Liu, Y.-C., Kao, Y.-J., Fu, C.-C., \& Hsiao, C.-J. (2009). A history of fine art in Taiwan. Taipei: Artists.

Liu, H.-Y. (n.d.). Investigation and maintenance plan for the overall restoration project of Taichung Railway Station. Retrieved from http://www.yjes.tc.edu.tw/tcts/a13.htm (August 20, 2017)

Reading Group, National Central Library. (Ed.). (1997). Text compiled by Ho Pei-Chi. Taipei under Japanese rule. Taipei: National Central Library.

Xia, G. (2005). Modernity and western modernity: From the cultural point of view. Beijing: Life, Reading, New Knowledge-Sanlian Book Store. 